\title{
PONDERING POSSIBILITIES OF THE BIBLICAL CRITIC AS PUBLIC INTELLECTUAL, PART ONE: PROBLEMATISING THE PUBLIC INTELLECTUAL AND THE IDENTITY OF THE BIBLICAL SCHOLAR
}

\author{
Johannes N Vorster \\ Department of Biblical and Ancient Studies \\ University of South Africa
}

\begin{abstract}
Is there a possibility to critically interrogate the hegemony of the type of historical approaches to the academic study of the Bible currently governing and regulating Biblical Studies? Against the background of inquiring how Biblical Studies can be effectively transformed, the biblical critic as public intellectual is submitted. The notion of public intellectual, however, is by no means an uncontested category and could replicate what its deployment would endeavour to subvert. The objective of this article is therefore primarily to problematise the notion of the public intellectual within a logic of representationalism with identity as organising principle. It is instead argued that the public intellectual be seen as a subjectivity engendered by an ethos of discursive practices emerging from difference. Utilising projects that theorise the critical rhetor and the public intellectual, I probe the possibility that the biblical critic likewise be seen as public intellectual, engendered by a peculiar ethos produced by its dispersion through discursive practices. This article constitutes a first part specifically problematising and theorising the notion of public intellectual and problematising the current identity of the biblical scholar.
\end{abstract}

Key Words: Biblical Studies; Biblical Discourse; Bible and Public; Public Intellectual; Disappearance of Public Intellectual; Biblical Critic; Representationalism in Biblical Studies; Ethos of Biblical Critic

\section{Introduction}

To consider the possibilities of the biblical critic as public intellectual is to think the possibilities of transforming Biblical Studies. To introduce the notion of public intellectual as a possible discursive site from where change can be thought is to inquire into the possibility of displacing Biblical Studies from its institutional moorings and locating it within multiple spheres of publics. It is an attempt to dismantle the hegemonies that have located it as object of inquiry in a very distant past and in a rather minute demarcated geographical space - hegemonies that have also constructed the regulatory mechanisms, keeping them stable, and marginalising, if not ousting, contending practices. Melanie Johnson-Debaufre writes that real transformation resides not only in the diversification of methods in incorporating cosmopolitan and multilingual biblical studies scholars, but in ensuring "that we are critically aware that all discourses including our own are situated in wide-ranging social-political debates, and that we are able to adjudicate the role of biblical 


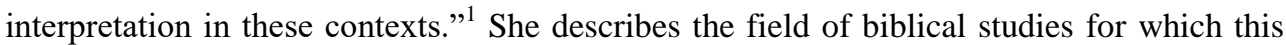
transformation is necessary as "a rich and multilocational set of discourses ranging around a group of texts," as a "complex and competitive debate.",

Biblical Studies within the context of "socio-political debates," even as a "complex and competitive debate," shifts us into the sphere of publics. Summons to understand the religious critic, or biblical critic as public intellectual or intellectual in an effort to signify the wider context of studies concerned with religion, or to locate Biblical Studies or Religious Studies within the larger framework of the Humanities and problematise claims made on its uniqueness in order to maintain disciplinary boundaries and fortifications, have been made for quite a while. Preceding McCutcheon's ${ }^{3}$ robust insistence and O'Connor's ${ }^{4}$ expanded proposal for the notion of public intellectual as site for the practices of Religious Studies, Dean has already considered the notion of the public intellectual as model for religious studies scholars, albeit then in service of what can be called a nationalistic 'spirituality.' ${ }^{5}$ It would not be too far off the mark to grant place of honour for the advocacy of the biblical critic as "a public, transformative, connected, or integrated intellectual"6 to Schüssler Fiorenza who has not only already pioneered the conditions for its making in her inaugural lecture as president of the Society of Biblical Literature in 1987 speaking as a 'connected critic' from the margins, ${ }^{7}$ but has also argued for its capacity for transformation within the context of the ethos of Biblical Studies as discursive practice. ${ }^{8}$ Joining Krister Stendahl, she visualises a "public health self-understanding of biblical studies graduate students." Commenting on the contemporary situation, Clines strongly observes that "the Bible is a book belonging to the public, to the society at large," and continues that "[i]t is a very public text." 10 Yet despite its "publicness,' biblical scholarship has done very little to inquire what can be called the performativity of biblical discourse within public spheres. When he summons his students to embark on a project to garner some inkling of what

1 Melanie Johnson-DeBaufre, "Mapping the Field, Shaping the Discipline: Doctoral Education as Rhetorical Formation," in Transforming Graduate Biblical Education: Ethos and Discipline, (eds. Elisabeth Schüssler Fiorenza and Kent H Richards; SBL Global Perspectives on Biblical Scholarship no. 10; Atlanta: Society of Biblical Literature, 2010), 330.

2 Johnson-DeBaufre, "Mapping the Field," 319.

3 Russell T McCutcheon, “A Default of Critical Intelligence? The Scholar of Religion as Public Intellectual," Journal of the American Academy of Religion 65, no. 2. (1997).

4 June O'Connor, "Response: The Scholar of Religion as Public Intellectual: Expanding Critical Intelligence," Journal of the American Academy of Religion 66, no. 4 (1998).

5 William D Dean, The Religious Critic in American Culture, (Albany: State University of New York Press, 1994).

6 Elisabeth Schüssler Fiorenza, "Rethinking the Educational Practices of Biblical Doctoral Studies," in Transforming Graduate Biblical Education: Ethos and Discipline, (eds. Elisabeth Schüssler Fiorenza and Kent H Richards; SBL Global Perspectives on Biblical Scholarship no. 10; Atlanta: Society of Biblical Literature, 2010), 393; see also Elisabeth Schüssler Fiorenza, "Introduction: For a Biblical (Wo/man) Scholar to Speak in the Ekklesia..." in Rhetoric and Ethic: The Politics of Biblical Studies, (Minneapolis: Fortress Press, 1999), 10; see also "Changing the Paradigms: The Ethos of Biblical Studies," in Rhetoric and Ethic, 44.

7 Elisabeth Schüssler Fiorenza, "The Ethics of Biblical Interpretation: Decentering Biblical Scholarship," in Rhetoric and Ethic: The Politics of Biblical Studies, (Minneapolis: Fortress Press, 1999), 19.

8 Schüssler Fiorenza, "Ethics of Biblical Interpretation," 26-28

9 Schüssler Fiorenza, "Rethinking Educational Practices," 382; also in "Changing the Paradigms: The Ethos of Biblical Studies," in Rhetoric and Ethic, 31. 
constitutes public knowledge, ${ }^{11}$ he can conclude that the Bible still has "a unique status in our popular culture,"12 because it can still be seen as a venerable social item, a "common possession of the culture," "a sign of civilization," and even as a "foundation of moral values" on condition that it corresponds with modern values. ${ }^{13}$

However, although the notion of 'public intellectual' has therefore quite often been used in relation to the religious or biblical critic and has been consistently regarded as a site for transformation, it has seldom been theorised and problematised within the realm of Biblical Studies. Being 'strategically anachronistic'14 it would be possible to relate the critical rhetor, in the person of the vir bonus of antiquity with the public intellectual of contemporary society, since both operate in the public sphere, both appear to address problems of public concern, advocating justice, insisting on democratic practice and civic duty, expose unfairness, dispute what is often taken as normal, represent the downtrodden and emancipate the oppressed. This is then the general view taken on the public intellectual within the field of Biblical Studies and the academic study of religion. However, this is also exactly the view that should be d since it borders on Modernism's Great Subject, the autonomous intellectual representing and inculcating those universal values cherished by spheres of the public and functioning in a teleology set on the emancipatory, that is, representing and liberating those that cannot do so themselves. In addition, it functions within a logic of representationalism where identity is the organising principle, thereby allowing for expansion and diversification, which in itself should not be denigrated, but not the type of transformation that interrogates the conditions that have normalised the very categories that have excluded and discriminated. Utilising projects that theorise the critical rhetor and the intellectual, I probe the possibility that the biblical critic as public intellectual be seen as a subjectivity, engendered by a peculiar ethos produced by its dispersion through discursive practices. Instead of a public intellectual featuring within a logic of representation, a public intellectual engendered by discourse is proposed.

The project "Pondering Possibilities of the Biblical Critic as Public Intellectual" is divided into two articles of which this one is the first. In this part, the focus will be mainly on a problematisation of the public intellectual with a proposal to approach and appropriate this category not from a logic of representationalism driven by the principle of identity, but rather as a discursive rhetorical construct. This part concludes with a brief problematisation of the identity of the biblical scholar, thereby setting the scene for the second article which will present current inquiries into the biblical critic as public intellectual, as well as implementing theoretical strategies for its invention in Biblical Studies.

\section{Who is the Public Intellectual?}

Various proposals have been made in attempts to define who the public intellectual is. Mailloux first distinguishes between academic and public intellectual and he insists, with a

\footnotetext{
11 They followed basically a two-pronged approach, namely via street survey based on responses to a questionnaire, and via references to the Bible in press specifically The Guardian for a period of six months during 1992.

12 Clines, Bible in Modern World, 79; care should be taken not to confuse "a unique status" with "being unique," the former condition being the product of discursive practices.

13 Clines, Bible in Modern World, 78.

14 I borrow this phrase from Stephen D Moore, "Illuminating the Gospels Without the Benefit of Color: A Plea for Concrete Criticism," in After "After Theory," and Other Apocalyptic Conceits in Literary and Biblical Studies (ed. SD Moore; SBL Resources for Biblical Study 57; Atlanta: Society of Biblical Literature, 2010), 28.
} 
cue taken from Stanley Fish, that non-academic public communication must be a defining criterion for the public intellectual. ${ }^{15}$ Despite the long term public effect of classroom pedagogy, the restriction of work to the academic situation disqualifies that academic from being a public intellectual. In some way or the other there must be public interaction, preferably both in address and in recognition, because discourse will be determined, in true rhetorical mode, by the public as addressees. ${ }^{16}$ However, there is room for a hybrid between the academic and the public intellectual. This is the academic who, in different rhetorical modes, interacts with and shares her/his expertise with the public. It is this class of the hybrid public intellectual that can assume four different rhetorical modes, namely those of the translator, the commentator, the inventor and the metacritic. The translator functions to make disciplinary knowledge accessible, both in its application to technological and societal problems, as well as the more general, practical philosophical tendencies of thought prevailing in the field of the disciplinary. The commentator assumes the role of the social critic, both explaining and criticising models of society and culture. Taking the cue from traditional thought, the inventor moves beyond the immediate public concerns to create alternatives, and the metacritic functions to critique the work of translators, commentators and inventors. ${ }^{17}$

The versions of the public intellectual Mailloux provides characterise the public intellectual as subject in the dissemination of knowledge, differing in degrees of agency, but all versions centre around a rather fixed corpus of knowledge. There is an autonomy bestowed upon the public intellectual as subject in the production of knowledge, restricted only by the boundaries defined by representation against which there should be some resistance.

Fuller describes the public intellectual as "ultimately an agent of distributive justice." 18 Distributive justice, however, should be widely understood, namely as not only pertaining to persons, but also as pertaining to ideas in particular as concerning their unfair dispersion and privileging. The public intellectual functions as a kind of catalyst allowing the resurrection of ideas appropriate to a particular context. As such, the public intellectual is an equalising agent in allowing for a more fair distribution in value between dominant and marginalised ideas. ${ }^{19}$ Since the public intellectual functions in the process of redressing the imbalance among ideas and allows for the emergence of excluded ideas, s/he can be described as a 'professional crisis-monger. ${ }^{20}$ The problem to find criteria for the categorisation of the public intellectual that could lead to the articulation of a definition can be seen in his earlier publication. ${ }^{21}$ The scope is admittedly wider, namely 'the intellectual' as such. Yet the very ambiguous, dichotomy-inspired, conflating categories contribute more to

15 Steven Mailloux, "Thinking in Public with Rhetoric," Philosophy and Rhetoric 39, no.2 (2006):140-146, finds the public intellectual definition of Fish too narrow; see also Steven Mailloux, "Contingent Universals:

Religious Fundamentalism, Academic Postmodernism, and Public Intellectuals in the Aftermath of September 11," Cardoza Law Review 24, no.4 (2003):1583-1604 where Stanley Fish, Edward Said, Richard Rorty and Alan Badiou are discussed against the background of Fundamentalism, Postmodernism and universalia such as human rights. From the perspective of rhetorical pragmatism and a foregrounding of Badiou's evental philosophy, Mailloux argues for the possibility of the academic to be also public intellectuals "offering new understandings and new vocabularies for discussing problems in the public sphere," 1600. Mailloux, "Thinking in Public," 143.

Mailloux, "Thinking in Public," 144.

Steve Fuller, "The Public Intellectual as Agent for Justice," Philosophy and Rhetoric 39, no.2 (2006):147.

Fuller, "Public Intellectual as Agent of Justice," 147.

Fuller, "Public Intellectual as Agent of Justice," 149.

See Steve Fuller, The Intellectual (Cambridge: Icon Books, 2005). 
an obfuscation of the notion of the public intellectual than to providing an explanatory definition. ${ }^{22}$ Fuller's construction of the intellectual is perhaps a good representation of its elusiveness, a characteristic he himself acknowledges. ${ }^{23}$ Besides the public intellectual as an autonomous agent ${ }^{24}$ with the capacity to identify crises, an identity is established between the public intellectual and ideals that are considered worthy, yet also proposing a mode of speech (entertaining) that yields a public intellectual as performer. Despite presenting a wide array of possible public intellectuals, the bias for a real authentic public intellectual is legitimated by a logic of the competitive.

After Nathan Crick $^{25}$ has problematised both the notions of public intellectual and public sphere, ${ }^{26}$ he indicates that two types of public intellectual are usually proposed, namely the Enlightenment and a Gramscian organic intellectual. The former sets as objective to translate èpistémè into techne, while the latter, which derives from Gramsci, is completely absorbed in praxis. ${ }^{27}$ Crick wants to steer towards a middle position, taking his point of departure in techne, not forsaking either the rationality èpistémè provides nor the action deriving from praxis. The public intellectual is consequently seen as an agent who reacts to the concrete socio-historical exigencies of the particular situation and the agency by means of which this action is to take place is via the creation "of enduring works that

22 For example, in characterising the notion of the "intellectual," the following are inter alia seen to be its features: dissenting from the position of the weaker, dichotomously personified in the persons of Protagoras and Socrates, "half prospector" and "half inquisitor," 17, "entrepreneurial optimist" and "paranoid pessimist" 18 , having an "oppositional consciousness, " 26 , concretising in "negative responsibility," 29 , having the capacity to gauge kairos, 48, the imagination to integrate the deployment of the "whole truth," 54-55, as opposed to "only the truth" of experts and censors, 54. In treating "frequently asked questions about intellectual" the two-pronged approach again emerges. Responding to the question of a typology of intellectuals, a classification that is more claim-based than theoretically argued is provided evoking the categories of "the career," the "source of appeal," "the exposure to current events," "the place in history," and those in defence of worthy "ideals," 122-132. Intellectuals are typified as career-oriented since for some their intellectual work serve to "make their name" while others do it "after they've made their name," 122; the source of appeal lies for some intellectuals in their constituency while others are client-driven, 123; in their exposure to current events some can be depicted as "weathervanes," while others are "echo chambers," 124125 ; in terms of their place in history, intellectuals function as ideological mouthpieces, but some are winners while others are losers, 127-128, and concerning the defence of worthy ideals, some intellectuals defend an absent ideal while others defend the "status quo," 129. The problems with this type of typology can easily be seen. Besides the oversimplified two-pronged approach, there is no reason why the ideological winner mouthpiece cannot also be the intellectual who wanted to make his career and later has made his career, and the same type of conflation can also be implemented as far as the other categories are concerned. Are these really public intellectuals or should these categories not rather apply to public figures? And is this suspicion not confirmed by his view on "entertainment" as the "key to public intellectual agency," the public intellectual being the person, to a large extent autonomous, whose ideas have outbidded others and have the lasting effect analogous to television shows with audiences contaminated by the virus from the "guest organism," an argument explored in Steve Fuller, "Entertainment as Key to Public Intellectual: Response to Welsh," Philosophy and Rhetoric 46, no.1 (2013):105-113, see specifically 108-110.

Fuller, Intellectual, 2.

24 See Fuller, "Entertainment," 105 where the public intellectual is required to be the "compleat rhetor," thereby assuming the existence of an ideal, universal rhetor, establishing an identity between a subjectivity and universality or totality. The existence of something such as "intellectual autonomy" features prominently in this construction of the public intellectual, see 106, and then 107 with references to the "autonomy of the public intellectual voice," a "Voltaire or Sartre" as autonomous subjects whose style marked them as "thinking through things for themselves," and the "normal science" of an academic as actually to "declare her reliance on other's work too loudly like a proud ventriloquist's dummy."

25 Nathan Crick, "Rhetoric, Philosophy and the Public Intellectual," Philosophy and Rhetoric 39, no.2 (2006):127-139.

26 Crick, "Rhetoric, Philosophy," 128.

27 Crick, "Rhetoric, Philosophy,"130. 
broadly influence cultural habits and institutional practices during their lifetimes." ${ }^{28}$ Although Crick rejects the metaphysical assumptions of a monolithic, uniform public and philosophy as a reservoir of universal truths as spheres from which the public intellectual is to be defined, he replaces the rhetorical situation as sphere of engagement with the philosophical situation, ${ }^{29}$ thereby privileging the ivory tower, confirmed also by the notion of 'enduring works' that are to function as response to contemporary socio-historical problems. Privileging Bitzer's notion of the rhetorical situation as basis invests the definition of the public intellectual with an essentialistic ontology, ${ }^{30}$ and its extension to what he calls the 'philosophical situation' appears to be an attempt to retain 'abstract ideas' as the reservoir for action. ${ }^{31}$

What can be seen so far: Despite recognising the public intellectual as part and parcel of the public sphere, in some constituted by the public sphere, there is a tendency to an ontology that manufactures a subjectivity infusing the notion of the public intellectual with a high degree of autonomy. It is as if a nostalgia to the Great Subject of the Enlightenment still determines the intellectual. The public intellectual has firmly been entrenched within an ontology of the subject as active, rational agent endowed with the capacity to determine how things really are and respond accordingly. This is coupled with a focus on the regime of ideas and their deployment in socio-political and cultural contexts. At the same time there appears to be a separation of intellectual work in the insistence on praxis. This is perhaps why one of the main issues foregrounded is the differentiation between the academic and the public intellectual. One cannot but help also to notice tension in the exigencies of the public sphere and the production of the public intellectual, the latter to transcend the contingencies of the context, if not in linking with Enlightenment universalia, then at least in universalia beyond the immediate.

Although the notion of the public intellectual can be linked to the Enlightenment and can be cast as a Western category by means of which issues such as democracy, citizenship, justice, moral and ethical relationships are foregrounded can be addressed, it has also emerged within the context of the colonised, albeit with slight differentiation. In both a 'descriptive and hortatory ${ }^{32}$ manner, Eduardo Mendieta ${ }^{33}$ introduces the postcolonial, trans- and postnational, diasporic, transmigratory public intellectual. ${ }^{34} \mathrm{He}$ offers a typology of the public intellectual by differentiating according to institutional space, consisting of the following types. State intellectuals are those who are in the service of the state and

28

Crick, "Rhetoric, Philosophy," 132

Crick's approach reminds strongly of Perelman and Olbrechts-Tyteca's distinction between the particular and universal audiences with the concomitant degree of engagement defined as persuasion versus convincing. It should at this stage also be noted that the rhetorical situation that functions as the ground for a definition of the public intellectual is related to Bitzer's version of the rhetorical situation, a "situation" constructed without any recognition of its construction. See in this regard Richard Vatz, "The Myth of the Rhetorical Situation," Philosophy and Rhetoric 6, no.3 (1973):154-161. For the pioneering work by Bitzer, see Lloyd Bitzer, "The Rhetorical Situation," Philosophy and Rhetoric 1, no.1 (1968):1-14). For a discussion on both Bitzer and Vatz, see Johannes Vorster, "The Context of the Letter to the Romans," Neotestamentica 28, no.1 (1994):127145 , in particular 138-144.

31 Crick, "Rhetoric, Philosophy," 138.

32 See Eddie, S Glaude Jr, "On Mendieta's Latino Public Intellectual," Nepantla: Views from South 4, no.2 (2003):257.

33 Eduardo Mendieta, "What Can Latinas/os Learn from Cornel West? The Latino Postcolonial Intellectual in the Age of the Exhaustion of Public Spheres," Nepantla: Views from South 4 no.2 (2003):213-233.

34 Mendieta, "Latino Postcolonial Intellectual," 220. 
represent the current ideology of the regime. ${ }^{35}$ Then there are the independent intellectuals who appear to be an extinct species, since they are neither bound to the institutions of the university nor the state and are inclined to focus on specific socio-political issues, and are guided by what can be called civic professionalism. ${ }^{36}$ Academic intellectuals, again, are guided by disciplinary professionalism, function within the institution of the university and either integrate their public intellectual enterprise in their academic conduct as part of their civic obligations or work pro bono. ${ }^{37}$ Finally, there is the category consisting of the "cosmopolitan and/or postcolonial intellectual" who must be seen against the background not only of globalisation, transcending in a spatial sense national boundaries, but also in the temporal sense of postcolonialism. The differentiating feature of this category is nonnationalistic, non-particularly-institutional, who will not only focus on "global and transnational issues," but can also function critically in the interaction between colonised and coloniser. ${ }^{38}$ Mendieta accuses contemporary renderings of the public intellectual of being "but a cloak for chauvinism and old-fashioned nationalism.",39

Yet his own rendering appears to be only a broadening of this nationalism to a type of monolithic, panethnic Latino public sphere, inclining to infuse the notion of the public intellectual with an ethnic universality and the United States of America as the prime target of criticism. ${ }^{40}$ Although Mendieta defines the public intellectual from the perspective of the public sphere, his neglect to historicise the latter both in terms of space and time restores the notion of a universal intellectual whose subjectivation according to particular social and political practices have not been taken into account. ${ }^{41}$ Juffer has shown that it is for that reason that Cornel West can function as a model of the charismatic intellectual for both African Americans and Latino intellectuals. ${ }^{42}$ However, it is precisely the introduction of Cornel West as example of the public intellectual that is problematised by Moya on the grounds of representational legitimacy interrogated by the way in which different sociopolitical and cultural imaginaries have constructed publics that cannot equally easily jettison nationalist identities and cultural tropes. ${ }^{43}$ Despite the valid critique launched at Western notions of the public intellectual, the same logic of representationalism, identity politics, an autonomous and authentic subject with the capacity to determine the realities of a situation, appear to inform the notion of public intellectual within this sphere.

\footnotetext{
Mendieta, "Latino Postcolonial Intellectual," 218.

Mendieta, "Latino Postcolonial Intellectual," 218.

Mendieta, "Latino Postcolonial Intellectual," 219.

Mendieta, "Latino Postcolonial Intellectual," 214-215, 219-220.

Mendieta, "Latino Postcolonial Intellectual," 215.
}

40 See Mendieta, "Latino Postcolonial Intellectual," 215, 216, 225. See also Glaude's criticism in Glaude, "Medieta's Latino Public Intellectual," 260. On the other hand again Medieta explicitly assigns the task to move away from "ethnocentrisms" to the role of the public intellectual, 228, yet does not really show how.

41 See Jane Juffer, "In Search of the Latino Public Sphere: Everywhere and Nowhere," Nepantla: Views from South 4 no. 2 (2003):263-268. This is also the problem of another participant in this debate namely Jacqueline M Martinez, "On the Possibility of the Latino Postcolonial Intellectual," Nepantla: Views from South 4 no. 2 (2003):253-256 who explicitly extracts the postcolonial public intellectual from the community and defines as a "conduit to the larger public sphere and the more established spaces where voices are heard and translated into the mechanisms of government and policy," 255.

42 Juffer, "Search of the Latino Sphere," 266, 267.

43 Paula ML Moya, "With Us or Without Us: The Development of a Latino Public Sphere," Nepantla: Views from South 4 no. 2 (2003):245-252. Her essay is a good example of how relations of power (with the United States of America, but also within a particular ethnic grouping) constructed different Latino public spheres, and from the perspective of "identity politics" she indicates to what extent the construction of Latino should be seen as a "marketing category," 250. 
It is worth noting that the tension between academic and public intellectual appears to be less within this context, that aesthetics, such as art and music, should also be recognised as possible constituents of public intellectuals, that the postcolonial context pervaded by the "shards left by the monstrous march of modernity" 44 require a change in the role of public intellectuals, as also do globalisation and transnationalism. Instead of a public intellectual as exposer or subverter of normativities, there appears to be a search for a public intellectual with whom can be identified, who can consolidate and unite. And yet, owing to the deep-seated social, political and cultural agonies colonialism has left as legacies, the historical and cultural fissures demand that representativeness has been prominently placed, high on the agenda, thereby simulating the Western public intellectual on a structural level.

\section{The Disappearance(s) of the Intellectual}

A topos that regularly occurs in literature concerned with the public intellectual is that of 'disappearance.' As a matter of fact, when the intellectual or public intellectual is discussed, disappearance, decline, demise, decay, death and displacement constantly hover in the background. Within the USA, for example, the publication by Russell Jacoby, The Last Intellectuals: American Culture in the Age of Academe, has not only identified an increasingly expanding vacancy in the academic culture sustained by a then younger generation of scholars, but frequently features when intellectualism in America is discussed, especially to confirm its absence. It stands to reason that his critique would not have gone without punishment and a host of publications have countered with demonstrations that intellectual life was alive and well in the USA, missing the point that he wanted to address the problem of a younger generation institutionalised within the academe where specialisation and professionalisation diverted public engagement. Despite this counterattack, he still features in accounts of the public intellectual specifically as authority on its disappearance. However, the invention of 'intellectual' or 'intellect' disappearances should not be restricted to Jacoby but is a recurring topos appearing whenever social anxieties, fears and moral discontentment emerge and their exigencies cast doubt on the available social coping mechanisms. Calavita refers to C Wright Mills who had already in the 1950's raised his concern that the "shrinking public audience," absorbed by "mass society," driven by consumerism at the cost of citizenship and democracy confused with market choice, may eventually also lead to the extinction of the intellectual. ${ }^{45}$ Also referring to Jacoby, she consents that a "dramatic "cultural restructuring" is what will be required, thereby problematising current culture with its anti-intellectualism, ${ }^{46}$ its loss of legitimised visions of justice, ${ }^{47}$ and its manipulation of knowledge production within the world of publication. ${ }^{48}$ In South Africa, the same lament can be heard when Jansen links the disappearance of the post-apartheid and university-based intellectual to a loss of authority as effect of a totalitarian managerialism that has besieged universities, government interference and control, and a change of campus ethos, alienating the intellectual. He limits

\footnotetext{
44 Glaude, "Mendieta's Latino Public Intellectual," 257.

45 Kitty Calavita, “'Goose Bumps,' and the Role of the Public Intellectual,” Law \& Society Review 36, no. 1 (2002):11.

46 Calavita, "'Goose Bumps'," 13.

47 Calavita, “Goose Bumps'," 13.

48 Calavita, "Goose Bumps'," 11. She also makes reference to several other types of "disappearances" of the intellectual, such as a decline in quality, discreditation as product either of the elite 12, or as product of the Enlightenment 13, or as representative within emerging democracies 13, 14, or its "death in Paris at the end of the twentieth century,"15.
} 
those he would regard as university-based intellectuals who would speak out on public concerns and challenge the status quo, to less than a dozen. ${ }^{49}$

Completely caught up in the totalitarian jargon of market terminology, and driven by a market methodology, Posner also discovers a decline in public intellectuals. ${ }^{50} \mathrm{He}$ distinguishes between two types, of which the first is on the brink of disappearance and of which the second exhibits inferior quality. The first is what he calls 'independent' intellectuals, whereas the second type is seen to be 'affiliated' and the affiliation is usually that of a university. ${ }^{51}$ His public intellectual is described as that of the "critical commentator addressing a non-specialist audience on matters of public concern." This critical commentator can be modified to be a "safe specialist," usually an academic, affiliated with a university, and who has acquired a noteworthy standing within the own field of expertise. ${ }^{52}$ As the engagement with the public increases, the measure of expertise decreases. The main reason for the decline in public intellectuals is a lack of quality control. ${ }^{53}$ In delineating who may pass as public intellectuals, Posner boasts a measurability criterion, namely frequency of citations both within the spheres of the media and the academy. ${ }^{54}$

Public intellectuals find themselves in the business of primarily producing what can be called "credence goods." ${ }^{, 55}$ However, constraints usually applicable for those in markets producing credence goods are dysfunctional in the case of the currently emerging public intellectuals. A public intellectual requires no warranty or licence for the product produced; there are no effective consumer intermediaries that may function in controlling the quality of their products; they are not subjected to reputational damage and adverse advertisement owing to poor quality and, for academics turned into public intellectuals, there is eventually little to sacrifice. ${ }^{56}$ Behind this sorry state of affairs, as far as public intellectuals are concerned, lie the forces of specialisation and professionalisation.

Di Leo commences with what can be called the 'discouraged' intellectual. ${ }^{57} \mathrm{He}$ alerts to the fact that, although we live in times where our knowledge of the world has increased and market demand for public intellectuals has grown, "public intellectualism in itself seems to be increasingly marginalised through shrinking levels of respect and relevancy." criticising Posner's Public Intellectuals: A Study in Decline ${ }^{59} \mathrm{Di}^{\mathrm{Leo}}{ }^{60}$ assigns the decline of the public intellectual also to the schism between the interests of academe and the

\footnotetext{
49 Johnathan Jansen, "South Africa: Intellectuals, the State and the Universities," in Poverty of Ideas - South African Democracy and the Retreat of Intellectuals," (eds. Gumede, William M and Dikeni, Leslie; Johannesburg: Jacana Media, 2009), obtained from University World News at http://www.politicsresearch.com/article.php. - December 13, 2009.

50 Richard A Posner. Public Intellectuals: A Study of Decline. Cambridge and London: Harvard University Press, 2001.

51 Posner, Public Intellectuals, 27.

52 Posner, Public Intellectuals, 5.

53 Posner, Public Intellectuals, 50-52.

54 Posner, Public Intellectuals, 167-220.

55 See especially Posner, Public Intellectuals, 7, 47-82.

56 Posner, Public Intellectuals, 77.

57 This is not his designation but he commences by the dilemma of the public intellectual to be taken seriously, see Jeffrey R Di Leo, "Public Intellectuals, Inc., symplokê 14 no.1-2 (2006):183.

58 Di Leo, "Public Intellectuals, Inc.," 184.

59 Di Leo, "Public Intellectuals, Inc.," 188-189.

60 Di Leo, "Public Intellectuals, Inc.," 183-196.
} 
interests of public-private sectors, ${ }^{61}$ from which is born first the "corporate intellectual," 62 more recently to be changed to what can be called the "brand intellectual."63

Ryan takes us to Great Britain during the Victorian age and how Bernard Shaw expressed his dismay "over the disappearance of the intellectual" as a feature of his time. ${ }^{64}$ However she indicates that the disappearance of the intellectual was already lamented by RH Horne in 1833 and compares this with contemporary lamentations on its absence or growing absence. She writes that it was especially since 1870 that "many voices have claimed that intellectuals are dying out" and that an anti-intellectual tendency could be identified, intellectualism often been tarnished with being foreign, or French. ${ }^{65}$ It should be kept in mind, though, that the noun 'intellectual' was rarely used before the last quarter of the nineteenth century in Britain, the usual designation being "men of letters," with Shaw preferring "man of genius," thereby turning his back on the professionalism that both the phrases "man of letters" and 'intellectual' implied, while at the same time criticising the intellectually impoverished contemporary public culture. ${ }^{66}$

In doing an autopsy on the cadaver of the public intellectual in Great Britain, Jennings also finds a rather negative anti-intellectualism, owing to intellectuality being associated with the French, as well as with a ruling elite that was actually drawn from a very "small number of interconnected families." 67 In addition, owing to multiple meanings that can be assigned to the term 'intellectual', a clearly demarcated social class of intellectuals was difficult to identify. After World War II a version, closer to that of France began to see the light of day, but contrary to the French whose commitment was to the preservation of truth, justice and human rights, "a distrust of abstract ideas combined with a delight in particularity focused patriotic nostalgia upon the peoples, places, and architecture of a muchrevered English landscape." ${ }^{68}$ However, the autopsy appears to reveal yet another phase that was part of the British public intellectual. In a postcolonial era also subjected to globalisation the intellectual has become little more than "public doom-monger." This situation has been enhanced with the election of 1979 which brought about an oppositional relationship between government and academics, the latter being subjected to typical neoliberal mechanisms, contributing to a loss of social status. ${ }^{69}$

Although France has generally been accepted as the birthplace of the public intellectual, dating the period of its birth to the Dreyfus Affair and the resistance against government, church and the military offered by intellectuals such as Emilé Zola and the social media, ${ }^{70}$

61 Di Leo, "Public Intellectuals,"188-190; also Jeffrey R Di Leo and Peter Hitchcock, "Introduction: Before the Beginning, After the End: Toward the New Public Intellectual," in The New Public Intellectual: Politics,

Theory, and the Public Sphere (eds. Jeffrey R Di Leo and Peter Hitchcock; Hampshire and New York, N.Y.: Palgrave MacMillan, 2016), xiv.

62 Di Leo, "Public Intellectuals," 192-195.

63 Di Leo and Hitchcock, "New Public Intellectual," xix-xx.

64 Vanessa, L Ryan, “'Considering the Alternatives...'- Shaw and the Death of the Intellectual," SHAW The Annual of Bernard Shaw Studies 27 (2007):176.

65 Ryan, "Shaw and Death of the Intellectual," 177-178.

66 Ryan, "Shaw and Death of the Intellectual," 178.

67 Jeremy Jennings, "Deaths of the Intellectual: A Comparative Autopsy," in The Public Intellectual (eds. Helen Small; Oxford and Malden: Blackwell Publishing, 2002:119.

68 Jennings, “Comparative Autopsy," 121.

69 Jennings, "Comparative Autopsy," 122.

70 See in this regard also David Carroll, "The End(s) of the Intellectual: Ethics, Politics, Terror," South Central Review 25 no.3 (2008):110-111 where Voltaire, as heroic intellectual conqueror, is also suggested as a possibility for the origins of the intellectual, thereby allowing for a possible origin of the public intellectual that could coincide with the beginnings of secularisation. 
this is also the country that has been most outspoken on the death of the public intellectual. Michel Foucault embarks on a problematisation of the designation 'intellectual' in a response to a question on whether 'intellectuals' talk too much. ${ }^{71}$ Despite a lot of talk about intellectuals, Foucault denies that he has ever met one; in fact, he denies that they exist. Instead of assuming the authority of the intellectual, he would prefer anonymity, thereby masquerading as the "masked philosopher." The performativity of this utterance should be considered, because in another published interview, Foucault not only acknowledged the existence of the intellectual, but even distinguished between 'universal' and 'specific' intellectuals. ${ }^{72}$ And, in another instance, he is quite explicit concerning the work of the intellectual when he says: "I would say also, about the work of an intellectual, that it is fruitful in a certain way to describe that-which-is by making it appear as something that might not be, or that might not be as it is." 73 It is therefore clear that the conditions which determine his utterance on the non-existence of the intellectual point into a different direction than simply being informative. Behind the outright denial of the intellectual's existence lies a discourse concerned with power, sociality, and the formation of the subject. The force of the utterance is to exchange authority from that of the philosopher and intellectual, from the autonomous individual to that of the public or the social sphere.

According to Carroll, Foucault "hoped to achieve what could be called the maximum level of discursive effect and a minimum or even zero degree of intellectual presence or authority." "This type of "disappearance" is probably also what inspires some of JM Coetzee's characterisations, the autobiographical reference having been completely absorbed by fictionalisation and third person narration. ${ }^{75}$ With Foucault's 'non-existent' intellectual, and Nethersole's portrayal of Coetzee as "reluctant intellectual" a different scenario has appeared that requires it to be contextualised, namely a discursive formation that performs the appearance of the "disappearance of man.",76

Already in 1966, with the publication of The Order of Things, Foucault announced the "disappearance of man." "77 Foucault's views on the intellectual, his preference for anonymity, ${ }^{78}$ his thoughts on what an author is, should all be related to this account of the human being's disappearance. In addition to his earlier boundary shifting works within the sphere of knowledge production, his later work on power and the technologies of the self cannot be by-passed in what can be used for a construction of a Foucaultian public intellectual.

\footnotetext{
71 Michel Foucault, “The Masked Philosopher," in The Essential Foucault: Selections from Essential Works of Foucault, 1954-1984 (eds. P Rabinow and N Rose; New York \& London: The New Press, 2003), 174.

72 Michel Foucault, "Truth and Power," in Michel Foucault: Power (vol. 3 of Essential Works of Foucault, 1954-1984; ed. JD Faubion; trans. R Hurley; London: Allen Lane The Penguin Press, 2001).

73 See in Johanna Oksala, How to read Foucault (London: Granta Books, 2007), 7.

74 Carroll, "End(s) of the Intellectual," 110.

75 See in this regard Reingard Nethersole, "JM Coetzee: Reluctant Public Intellectual," African Yearbook of Rhetoric 2 no.1 (2011):44, 47, 50.

76 I have to retain the masculine in this sense, not only because of referencing to the work of Foucault, but also because the demolishing of the Great Subject and the grand narratives in which "he" acted also implied how the processes of knowledge production were regulated by gender. I will therefore avoid using (sic) in every instance.

77 To an extent the complete The Order of Things represents a discourse disputing the épistèmè granting central position to the human being in the process of knowledge production. For specific reference to its disappearance, dissolution, death or end, see Michel Foucault, The Order of Things: An Archaeology of the Human Sciences, (New York: Vintage Books, 1994), 383-387.
}

78 In a similar manner also Coetzee, who prefers to shy away from public prominence. 
The disappearance of the "human person" According to Foucault this happened from the end of the eighteenth century and into the beginning of the nineteenth century, when a shift in èpistémè took place, that is when the threshold from the Classical period to Modernity was crossed. Using the painting Les Meninas by Diego Velázquez as point of departure, Foucault illustrates how representationalism functioned as unifying principle for the èpistémè produced during the Classical period. He demonstrates how all the "interior lines of the painting ... pointed towards the very thing that is represented, but absent." All these interior lines point towards the spectator as person, who features external to the painting, but who is not foregrounded as unifying principle. For the èpistémè of the Classical period, that is up to the end of the eighteenth century, "man did not exist," 80 or to put it differently, "there was no epistemological consciousness of man." ${ }^{\prime 81}$ At stake was the correspondence between being and language and, as far as the human being was concerned, the question concerned the extent to which human nature could be represented by the proper definition. This scenario changed when Modernity entered at the beginning of the nineteenth century. Referring again to the painting Les Meninas, with the entrance of Modernity, the real spectator slips into the "place of the king." 82 Dreyfus and Rabinow aptly articulate this shift: "Man, who was once himself a being among others, now is a subject among objects. But Man is not only a subject among objects, he soon realises that what he is seeking to understand is not only the objects of the world, but himself. Man becomes the subject and the object of his own understanding." 83 What marks the change between the representationalism of the Classical period and Modernity, is not a disappearance of representation, but the foregrounding of the conditions that make representation possible. That which was absent has become present with such a force that it not only became both object and subject of knowledge, but 'man' emerged also as "organizer of the spectacle in which he appears." 84 In proposing an analytic of finitude, Foucault writes: "It is no longer their identity that beings manifest in representation, but the external relation they establish with the human being." 85 From the perspective of the human being, the abandonment of the representational order requires the ordering according to the laws of the things themselves, according to the laws of life, production and language. However, they are not suspended in a vacuum but exist only in relation to the human being. Again in the words of Foucault: "In the middle of them all [life, production and language], compressed within the circle they form, man is designated - more, required - by them, since it is he who speaks, since he is seen to reside among the animals (and in a position that is not merely privileged, but a source of order for the totality they form: even though he is not conceived as the end-product of evolution, he is recognised to be one extremity of a long series), and since lastly, the relation between his needs and the means he possesses to satisfy them is such that he is necessarily the principle

\footnotetext{
79 Foucault consistently used "man" as reference to human beings. In attempting to represent his work and explore the possibilities he has opened for the conceptualisation of the public intellectual, I will replace "man" with "human being" or "person" as far as possible.

80 Foucault, Order of Things, 3-16, also 307-308.

81 Foucault, Order of Things, 309.

82 Using the painting Les Meninas as framework of discussion, Foucault indicates how the spectator occupies the same position as the king and his wife reflected in the mirror. See Foucault, Order of Things, 307-312.

83 Hubert L Dreyfus \& Paul Rabinow, Michel Foucault: Beyond Structuralism and Hermeneutics - with an Afterword by Michel Foucault (New York: Harvester Wheatsheaf, 1982), 28.

85 Foucault, Order of Things, 313.
} 
and means of all production." ${ }^{86}$ Human consciousness has become the "originating subject of all knowledge and practice." 87 Occupying the centre, this originating subject of all knowledge and practice, produced knowledge in terms of itself and viewed itself as the only source of knowledge production.

However, although the human being has become the point of orientation of all knowledge production, there is an ambiguity, a paradoxicality which is fundamental, because as governor, s/he is governed, the king is enslaved, because knowledge also preceded $\mathrm{him} / \mathrm{her}$. The human being inherits a legacy of language, there is a history preceding his/her birth and s/he becomes an instrument of production. In the positivity of the knowledge which is disclosed and which is produced, "[m]an's finitude is heralded.",88

The manner in which language has 'returned', turning around a long history of lurking behind a logic of representationalism, confirms on the one hand the disappearance of 'man,' and the effacing of all his 'representations,' the philosopher, the intellectual, the author, 'his-stories,' even as it at the same time, on the other hand discloses its creative, materialising, constructing capacities. Both the challenge and the dilemma now reside in the question: "What is language, how can we find a way round it in order to make it appear in itself, in all its plenitude"? ${ }^{89}$ The dilemma is to make it appear in a form unmediated by language, the impossibility of escaping symbolisation as producing the knowledge we have, in short to make it appear without recourse to language itself. The challenge is to make it appear in the plenitude of its creative capacities, to make it appear in the endless array of possibilities it offers. Oksala indicates that Foucault's "return of language" coincides with philosophy's "linguistic turn" whereby human experiences are to be seen, not as represented by language, but constructed or created by language. The finitude of 'man' is confirmed by the productive possibilities of language: "[W]e can only experience something that language makes possible for us."

It is against the background of the disappearance of 'man' that the author also disappears and becomes replaced by the "author function." 90 An author does not feature as the originator of discourse, the subject that brings a writing into its existence. Writing for Foucault, creates "a space into which the writing subject constantly disappears," "91 the reason being that writing identifies with "its own unfolded exteriority." 92 Preceding writing, a discursivity exists of which writing partakes, just as it is again taken up into discourse that was not of its own creation. As such the author also "cancels out the signs of his particular individuality", and "[a]s a result the mark of the writer is reduced to nothing more than the singularity of his absence; he must assume the role of the dead man in the game of writing." 93 The "author function" refers to the "characteristic of the mode of existence,

Foucault, Order of Things, 313; the masculine has been retained because it is crucial to the argument, although Foucault may not have intended gender sensitivity.

87 Michel Foucault, "On the Archaeology of the Sciences: Response to the Epistemology Circle," in Michel Foucault: Aesthetics (vol. 2 of Essential Works of Foucault, 1954-1984; ed. JD Faubion; trans. R Hurley; London: Allen Lane The Penguin Press, 1998), 333.

88 Foucault, Order of Things, 313.

89 Foucault, Order of Things, 306.

90 Michel Foucault, "What is An Author?" in Michel Foucault-Aesthetics: Essential Works of Foucault 19541984, vol. 2 (ed. James Faubion; transl. Robert Hurley and others; Harmondsworth: Penguin Books, 1998), 206-209, 211-216.

91 Foucault, "An Author?," 206.

92 Foucault, "An Author?," 206.

93 Foucault, “An Author?," 207. 
circulation, and functioning of certain discourses within a society." ${ }^{94}$ The category of "author function" signifies the departure from the author as autonomous subject creating a medium that could function in the liberation of humanity, ${ }^{95}$ but it becomes a principle for the organisation, classification, dispersion and discrimination of a peculiar form of discursive existence.

In response to a government-initiated invitation addressed to 'intellectuals' in France to participate in debating the country's socio-economic problems, Lyotard ${ }^{96}$ argues that what the government desires cannot be delivered, because the real intellectual has been buried. However, if one locates the notion of the intellectual within the wider ambit of Lyotard's work, it would be possible to identify three types of intellectuals, despite a severely critical attitude towards 'intellectuals,' and despite the fact that he would probably not have preferred the designation 'intellectual.' It will become clear that it is again the logic of representationalism with its foregrounding of the autonomous active subject that is what problematises the notion of the public intellectual.

Considering the above-mentioned government-initiated invitation from the perspective of the type of social responsibilities intellectuals might shoulder, Lyotard associates the intellectual with universality. He writes: "[I]t seems to me that 'intellectuals' are more like thinkers who situate themselves in the position of man (sic), humanity the nation, the people the proletariat, the creature, or some such entity. That is to say, they are thinkers who identify themselves with a subject endowed with a universal value so as to describe and analyse a situation or a condition from this point of view and to prescribe what ought to be done in order for this subject to realise itself, or at least in order for its realisation to progress." ${ }^{.97}$ This type of intellectual, according to him, belongs to the past, to "another age" 98 when the idea of a universal subject was still appropriate and history was constructed as a grand narrative concerned with the liberation of the subject as self-realisation. ${ }^{99}$ The grand narratives that determined the construction of history could be divided into the Enlightenment, the emergence of capitalism and the reaction of Marxism, but all three were centred around the idea of redemption, the redemption of the universal subject. For the Enlightenment it meant liberation from ignorance, for capitalism it meant the capacity to provide for material needs in a free market, and for Marxism freedom for the proletariat via labour. ${ }^{100}$ By universalising thought, intellectuals functioned in these totalitarian discourses as agents for the self-realisation, the redemption of humankind. However, new technologies have emerged which no longer provide the signs that could legitimate a thinker who can identify with a universal subject. There is no longer a universalising thought that can unite the variety of responsibilities evoked by these new technologies within a coherent system according to a common purpose. According to Lyotard: "It is precisely this totalizing unity, this universality, that thought has lacked since at least the middle of the twentieth century."

\footnotetext{
Foucault, “An Author?,” 211.

95 For the way in which Foucault's "What is An Author?" can be seen as a product of discursive difference disrupting Sartre's What is Literature?, see Oksala, Foucault, 38-39.

96 Jean-Francois Lyotard, "Tomb of the Intellectual (1983)" in Political Writings (trnsl. B Readings with KP Geiman; London: University College London, 1993), 3-7.

Lyotard, "Tomb," 7.

Bill Readings, "Foreword: The End of the Political," in Political Writings (trnsl. B Readings with KP Geiman; London: University College London, 1993), xxii.

100 See Lyotard, "Tomb," 6; also Readings, "Foreword," xxii.

101 Lyotard, "Tomb," 6.
} 
narrative ethos, there can no longer be an 'intellectual' who can identify with a universal subject of whatever kind. Neither should there be, not only because such an intellectual belongs to a past age, but also because this decline in universalising thought liberated from a totalising obsession which can only be restored with injury to those parties excluded by the universalising idiom. ${ }^{102}$

Before proceeding to the other types of intellectuals that can interpretatively be identified in Lyotard's work we need to see that Lyotard problematises the intellectual on the basis of what he calls discursive legitimacy. By virtue of what authority can a thinker speak on behalf of others? What legitimates an intellectual to claim competency to venture thought on behalf others? This, according to Readings "is the root of Lyotard's attack on intellectuals, experts, and big brothers." ${ }^{103}$ And Sim $^{104}$ demonstrates that Lyotard gave clear indication of finding "something basically dishonest about the nature of intellectual activity," specifically as it quite often relates and associates with authority. Even the traditional philosopher can be seen as "too often being 'a secret accomplice of the phallocrat," and philosophy of being "the West's madness" which "never ceases to underwrite its quests for knowledge and politics in the name of Truth and the Good.",105

Discursive legitimation, happens by virtue of a politics of representation. A politics of representation operates on the possibility of two premises, namely the representability of reality and the possibility of achieving consensus. Both these premises are driven by the assumption of homogeneity. Furthermore, the politics of representation requiring discursive legitimation, operate in close relationship with the politics of redemption. A politics of redemption claims the potential to achieve a redeemed society, whether that redemption be from ignorance, poverty, or slavery. However, redemption requires a 'redeemer,' who can speak "on behalf of the other." This redeemer or intellectual would be legitimated by a tradition of discourse extending from the Enlightenment which consistently strived towards emancipation, whether that emancipation was from ignorance, that is, lack of knowledge leading to self-maturity, from lack of material needs, or from the exploitation of labour sold or exchanged for a wage supposedly of equal value. The discourse of emancipation during the period of Western Modernity, has been a discourse intent on the removal of lack in whichever modus it has appeared, because lack suggests a certain incompetence, or immaturity to take things in your own hands. Lack in this context refers to the absence of a hand because it is being held by a person in authority. It therefore implies reliance. With a play of words, Lyotard argues that it was the grip of the manceps from whom the emancipation had to be actualised, thereby shaking off the condition of mancipium. ${ }^{106}$ Anyone in the condition of a manceps is in a state of lack, that is, "missing a hand." 107 Modernity has claimed to take things in its own hand in an attempt to liberate humanity. And yet, despite its claim, childhood has continued. Besides the fact that it has become clear that the grip can never be evaded, a politics of redemption again presupposes the possibility of the universal. Concerning the 'intellectuals' of the Enlightenment and their

\footnotetext{
Lyotard, "Tomb," 7.

Readings, "Foreword," xxi.

Stuart Sim, Jean-François Lyotard (London and New York: Prentice Hall Harvester Wheatsheaf, 1996), 116.

Sim, Lyotard, 117.

106 The word manceps refers to the person who takes hold, who takes possession of and who appropriates the other, while mancipium refers to both the gesture of taking hold and to the object that has been taken hold of. See Jean-Francois Lyotard, "The Grip" (1990)" in Political Writings (trnsl. B Readings with KP Geiman; London: University College London, 1993), 148.

107 Lyotard, "Grip," 152.
} 
attempt at an educational system that could have strengthened the freedom of the citizen, he says: "The 'intellectuals' who made up the Aufklärer and their nineteenth-century heirs thought that propagating education would strengthen the freedom of the citizen, would get rid of political sectarianism, would hinder wars. Today no one expects teaching, which is discredited everywhere, to train more enlightened citizens..." 108 Since there is no universal victim, there ought not to be any 'intellectuals' ... and yet the West has, according to him, been blind for this fact since the $18^{\text {th }}$ century. ${ }^{109}$

Although the demise of the intellectual, as narrator of the grand-narrative, is claimed by Lyotard, thinkers, artists, writers, philosophers and intelligences are not denied. A second type of "intellectual, ${ }^{110}$ emerged as the product of new technologies, ${ }^{11}$ but these "cadres are not intellectuals as such" but can at best be seen as analysts within specific domains who have the object to cultivate "the best possible performance in that domain," and the best possible performance has to be defined by the "best input/output (cost/benefit) ratio relative to an operation." "112 These 'cadres' neither question the boundaries nor the nature of their domains, but work within the "received compartmentalisation of realities and the received criterion for the evaluation of actions." 113 They therefore acquire their discursive legitimation by virtue of their expertise within the particularity of their domain and by virtue of their capability to achieve the highest productivity. However, if we relate these 'cadres' to Lyotard's views on the unipolar state, it would be possible to see them as its agents at work within the discursive spaces that have emerged as effects of the new technologies.

The unipolar state consists of the complicitious relationship between the technologies of the state and the economy, harnessing science and technology to serve its ends. ${ }^{114}$ Within the unipolar state, which can be seen as terminus, the end product of modernity, all activities are governed by the mechanistic model, of which the principle is the achievement of the highest equilibrium of cost and benefit. Owing to this all-pervading principle, all realities, all activities, all parties, in short everything, becomes representable in terms of a homogeneous mode. As such differences cannot exist but are absorbed by achieving consensus in terms of an idiom constituted by the principle of achieving an equilibrium of cost and benefit. It can be shown how the mechanisms of the unipolar state have also pervaded the academic life at the University. Since the University has become a product of the mechanistic model, as can be seen by the force the cost/benefit principle has acquired in the up- and downscaling of disciplines, the design of curricula, the introduction of constant ratings on all levels and the operation of so-called consensus concretised in performance 'agreements,' the academic has lost her power except "insofar as it is mediated by a

108 Lyotard, "Tomb," 6.

109 Readings, "Foreword," xxii, summarises as follows: "The intellectual, as a modernist creature, rationalizes history by means of abstraction, constructing a grand narrative of the liberation of a subject as selfrealization."

110 Lyotard's default contempt for the notion of intellectual perhaps invalidates the use of this designation for the second group I wish to demarcate. However, these professional thinkers function according to him as substitutes for the "intellectual" which may warrant this designation.

111 These new technologies are, technology, economy, the state and science and a hierarchical combination of science and technology in subservient relationship to the combination of state and economy (see JeanFrancois Lyotard, "New Technologies (1982)" in Political Writings (trnsl. B Readings with KP Geiman; London: University College London, 1993), 14-18.

112 Lyotard, "Tomb," 4.

113 Lyotard, "Tomb," 4.

114 See Lyotard, "New Technologies," 14-15; also Readings, "Foreword," xix. 
representational system" which consists of various levels of managers. Lyotard writes: "Working becomes the carrying out of operations, subjected to imperatives of time and even of norms foreign to its content, ultimately dictated by the axiom (which manages the 'managers' in the first place) that 'economic' society is a machine and ought to obey the rule of the best possible cost/benefit ratio..." All activities have consequently been divorced from their meaning and the questions and answers that would have provided meaning to activities have all been absorbed by the criterion of cost versus benefit. Pushing each activity to its optimum within the ratio of cost/benefit is an associated, attached apparatus, "made up of specialists qualified to guarantee its optimal functioning." 116 These specialists derive their authority from competencies acquired to ensure optimal performance; they respond to the responsibilities required from them within a particular field, but they have no discursive legitimation external to a particular field. Since the idiom of the mechanistic model, with its techno-economic rationality, has repelled the discourse of humanitas at the Universities, and the humanities have not yet succeeded in providing a formulation dealing with the meaning of existence and questions of citizenship (and most probably cannot), academics have become 'academicians,' who function only as transmitters, but whose speaking does not reach outside the specifics of their disciplines... and according to Lyotard, neither should it. ${ }^{117}$ They may contribute to the invention of new mechanisms to maximise performance, but they do not have the authority to perform outside their domain of expertise.

Lyotard's problematisation of the intellectual authority is, however, not a totalitarian swipe with the back of the hand to clear the table of all public intellectual engagement. On the one hand it would be quite possible for the 'specialists' or 'experts' to publicly transmit the information appropriate to their domain. However, since these specialists have been subjectivated to the principle of the mechanistic model, namely to achieve an optimal relation between expenditure and production, it is unlikely that this information will be anything but the work of accomplices, and therefore operating in the mode of the instructive or propagandistic. On the other hand would it be possible to identify a third type of 'intellectual' where the possibility emerges to witness to a dissensus among parties where the language of the one cannot fit into the idiom of the dominant, cannot be heard or said in the language of the dominant party. This brings us to yet another component in Lyotard's configuration of intellectual activity, namely the notion of the differend. The differend must be distinguished from oppositionality and to an extent also from difference itself. Differends occur in societies where various phrase regimes or idioms conflict with each other. Lyotard writes: "I would say that there is differend between two parties when the 'settlement' of the conflict that opposes them appears in the idiom of one of them while the tort from which the other suffers cannot signify itself in this idiom." ${ }^{118}$ Consensus, documented in agreements and contracts, does not prevent the injury suffered by those whose idiom has been denied the right to speak; representation, institutionalised in the relationship between boss and worker, does not guarantee that the unspeakable be said and the silence be heard. Political debate, negotiation and public communication - the staging

115 Lyotard, "New Technologies," 14-18.

116 Jean-François Lyotard, "Dead Letter (1962)," in Political Writings (trnsl. B Readings with KP Geiman; London: University College London, 1993), 33-40, 35.

117 Lyotard, "Dead Letter," 37, but also "Tomb," 5.

118 Jean-François Lyotard, "The Differend (1982)" in Political Writings (trnsl. B Readings with KP Geiman; London: University College London, 1993), 9. 
of public debate - does not offer a space for the articulation of the phrase which does not fit into the idiom in which the conflict is to be settled.

The space occupied by the intellectual who can be constructed from Lyotard's notion of the differend, is that of liminality, the space between two parties in conflict, but where the existence of the idiom of the one is neither allowed, nor recognised. The dissensus cannot be expressed in its own terminologies, in its own language, manufactured from its own values and conditions, but has to avail itself of regulating phraseology of the dominant idiom. It is to this differend that the third type of intellectual must bear witness. Lyotard's intellectual engages in minoritarian politics which operates to make the unspeakable said, to give witness to heard silences. It is not simply oppositional, it is not simply difference of opinion, or an alternative position within the same idiom, but his intellectual operates in the sphere of radical dissent, not clamouring for political representation, but arguing against a politics of representation, not seeking consensus, but exposing the implied homogeneity presuming compliant cooperation, not joining in the search for a redemptive resolution and a judgment on right or wrong, but disclosing the implicit grand-narrative and its totalitarian discourse of certainties.

\section{From 'Who is' to 'How are Public Intellectuals formed'?}

We have seen that there is no clear definition of the public intellectual, as a matter of fact the lingering remains and traces of a metaphysical ontology informed by a subtle Essentialism inhabit the resurrected discourse on its nature and functions. We have also seen how this metaphysical ontology has been questioned by Foucault and Lyotard and how alternatives have been suggested that buried representative constructions, laid to rest the autonomous intellectual and cast a doubtful glance over specific, labour intensive and productive specialists or experts. To assign a fixed identity with particular features, or whose constitution is the product of concrete tasks, duties or obligations, to personalise and individualise what could maybe be called civic capacities have been problematised. It has instead become clear that the public intellectual's mode of existence appears to be discursive, that it emerges from discursive difference and disruption rather than from continuity and identity.

Just as the disappearance of the public intellectual requires interpretation from a rhetorical perspective, and can be interpreted as a "usefully mobilising fiction," the public intellectual can be seen as a rhetorical construct. Referring to Foucault's response that he, as the "masked philosopher" has never encountered an intellectual, Carroll concludes that the meeting indeed could not have taken place, because the "intellectual is a mythical figure rather than a real person, a rhetorical abstraction and personification of a national or universal subject." ${ }^{119} \mathrm{He}$ indicates that Foucault's anonymous participation was an attempt to allow "discourse to function on its own, its authority coming exclusively from itself and not from him." It is therefore not an autonomous real individual with reputation and capacity producing addressed discourse but discursive practice that has produced and has lent authority to a personage. If there remains any possibility to still deploy the notion of public intellectual its shift to its discursive mode of existence and performance is of paramount importance in order to avoid the replication of an Enlightenment subject representing and incorporating what societies present as universal, natural, normal and civil.

119 Carroll, "End(s)," 110. 
And yet, while the rhetoricity of the public intellectual has been recognised, the discursive effects of a realist paradigm for its construction still pervade this proposal. While the illusionary pretension of representation has gradually been exposed, there has also been a concomitant concern regarding the ethics that were maintained by the conditions that constructed the intellectual as mythical personage. Carroll for example writes: "The demise and lack of authority of intellectuals cannot thus be seen as an entirely positive phenomenon, for an ethical void remains if not to be filled then at least confronted, since the responsibilities and obligations of citizens have in no way diminished..." ${ }^{120}$ Carroll's concern, writing within the context of the USA, is political and military, is that of terrorism and torture and the way the latter is justified as necessary for the future of democracy. However, the question is whether the politicising of the economy, visibly present in the increasing authority of corporatism and fuelled by neoliberalism, does not require that the discursive formation of the public intellectual be considered? It should also be asked whether the recognition of an "ethical void," the concerns with the uncontrollability of the military, and the frightening fraternity of economists and politicians, are not in themselves rhetorical constructs, concerned articulations struggling to claim a particular authoritative representation? How can we possibly imagine the active voice of $a$ person to remedy, protest or interrogate discursive formations that have invaded, formed and controlled publics with the forceful efficiency of tanks roaring in display at military parades on the very sites created for public interaction?

Carroll proposes that, in the agonistic agony of contesting parties, representative authority can no longer be claimed for a "universal subject," but that discursive legitimacy can be claimed for a "minimalist principle that is derived from no particular philosophical, political, moral, or religious heritage, that is associated with no one nation, group, religion, culture, or ethnicity more than with another, that belongs to no one and thus to everyone... [a] principle that is not rooted in a universal idea of 'man,' but rather in...the respect of individual human beings and living human bodies." This minimalist principle is then found in an essay by Albert Camus published in Combat during 1946, entitled "Save bodies." As a public intellectual, Camus is then constructed in terms of degrees, "more of a specific intellectual than a universal intellectual," but retaining "some aspects of the universal intellectual," enacting an interpellating principle, demanding intervention on behalf of the human body.

Although Carroll's presentation and selection of Camus indeed problematise the notion of the intellectual and clearly exhibit an awareness of the problematics, the constructedness of his proposal should not be ignored. Having enacted a discourse of pain and suffering within which an ethical void in American politics can be situated, a historical narrative from France's colonialist past functions as analogical situation for the creation of an exemplary protagonist in the person of Camus. We need to keep in mind the vast differences in discursive formations that have taken place not only since the lifetime of Camus, but also with respect to different continents inhabited by publics differently formed. It should not go undetected that the reader has been transported to France and to France's history, the site of events closely associated with the origins and traditions of "the intellectual." Worthy of admiration, and appropriate as example, as Camus may be, his construction serves to legitimate the selection and appropriation of what can be seen as a fundamental, universal, in-the-interest-of-all-humans principle. Without in any way devaluing this interpellation within its context, should the articulation of a minimalist

120 Carroll, "End(s)," 117. 
principle function as criterion for what constitutes a public intellectual? Should we not also recognise that the articulation of minimalist principles, such as cogito, ergo sum, or even its expanded version dubito, ergo cogito, ergo sum in effect does not inhibit universal claims or problematise the right to universal representation? It has become "academically incorrect" to adhere to a universal public intellectual, representing the values of humankind, but it is a question whether Camus can, on the grounds of a minimalist principle that is actually universally applicable, be seen as a "specific intellectual." Despite Carroll's recognition via Foucault that the intellectual is a "rhetorical abstraction," and Lyotard's rejection of a "totalizing unity," implicating the existence of an intellectual, representing the obligation of civic and democratic duty, the problematics of a 'realist' framework for thought on the intellectual still haunt this proposal and indicate to what extent the discursivity of realities has not yet been accepted.

From a Latino perspective, distinguishing between a cultural and intellectual scene, Mendietta lambasts narratives concerning the disappearance of the public intellectual posing as enlightened cosmopolitanism, yet which can be seen as nothing but "cloak for chauvinism and old-fashioned nationalism." What he misses in studies concerned with the public intellectual is the notion of the "postcolonial intellectual" which he particularises as the "prophetic intellectual" to be found in the person of Cornel West. Although critical of versions of the public intellectual and quite aware of its Enlightenment roots and identity established with the totalising unity of universal 'man,' he opts to retain the category, though not in the sense of rejuvenation. ${ }^{121}$ The conditions constituting the rhetoric of the public intellectual, however, disclose striking similarities with the construction of the public intellectual within a realist frame of reference. The topos of absence of intellectuals within the Latino sphere is first claimed and then modified as a lack of the assertion of their presence. ${ }^{122}$ The public intellectual is a rational agent, although defined by space, institutions and topics to be addressed. ${ }^{123}$ Firmly embedded within a politics of identity, the public intellectual within this context will be a hybrid who must have the capacity to transcend while at the same time forging identities across borders in an effort to represent a "postuniversalistic cosmopolitanism," yet also performing in consolidating a panethnic Latino sphere. The public intellectual here constructed also functions as emancipator, not only from oppressing American discourses, from racism, from institutional scorn, but also in working towards the achievement of an incompleted Enlightenment.

A significant, but largely ignored study within this field lends further credibility to the notion of the public intellectual as a rhetorical construct, a discursive product always in the process of becoming, largely produced by interacting spheres of the public in contestation with each other. From the perspective of Sociology, Townsley ${ }^{124}$ takes her point of departure in the public intellectual as a trope in the USA, specifically analysing how this trope has been deployed within the elite public sphere. Although discursivity as such does not feature prominently in this article, adopting a tropological approach already removes the notion of public intellectual from the possibility of individual autonomy and from performing in the active voice while it firmly situates within the social relations of public spheres and at the same time opens the possibility to enquire as to its performativity. Instead of autonomy and individuality, instead of universal or national representation,

121 Mendieta, "Latino Postcolonial Intellectual," 215.

122 Mendieta, "Latino Postcolonial Intellectual," 215.

123 Mendieta, "Latino Postcolonial Intellectual," 218.

124 Eleanor Townsley, "The Public Intellectual Trope in the United States," The American Sociologist 37 no. 3 (2006). 
rhetorically constructing the public intellectual shifts enquiry to the nexus of social and cultural capital and the structures by which they are maintained. ${ }^{125}$

Several mechanisms useful for a perspective on the public intellectual as rhetorical construct emerge. Taking into consideration the category public intellectual in terms of spatiality and temporality, two public spheres are demarcated, namely that of academia and that of the media, specifically the field of journalism, with 1987 as the date of its adoption within the elite public sphere of the USA. How this trope performed in both the New York Times since a review of Jacoby's Last Intellectuals and in the Chronicle of Higher Education forms the field of enquiry. In analysing the manner in which Jacoby's publiccation was reviewed in the New York Times, she indicates how a selective genealogy, elevating some as models, functioned as primary mechanism for the granting of public intellectual status. This genealogy refers to the past, specifically to the $1960 \mathrm{~s}$, as a distinctive period in the formation of intellectuals, whose exemplariness can then also be compared with the present where the political sensitivity appears to have been spatially numbed by the constraints of a particular sphere, the university. Related to making of a genealogy, the "public intellectual" always performs in a relationship of the attribution of status, or 'nomination.' This concerns two parties, namely the attributor and the recipient. ${ }^{126}$ As a recipient of attributed status and by its insertion in social relationships it demolishes not only the measureability criterion but also prevents an essentialistic claim on individual capacity and confirms the public intellectual as product of regulatory practices relative to particular public spheres. It can be seen as technique that both includes some into the circle of the distinguished, while at the same time it excludes others. It stands to reason that the attribution of status will be relative to a hierarchy of values, inter alia those values that have also constituted social hierarchies. Related to the mechanism of nomination or attribution of status is also what can be called competitive comparison. Townsley indicates how the trope of the public intellectual has emerged within a field of similar tropes during the same period and has proven itself to be more successful in signifying a positive connotation, specifically in pointing to moral concerns. ${ }^{127}$ In the discrediting and the othering of the university and the academy, whether by academics themselves or by journalists, public intellectual rhetoric appears to be deployed as a mechanism. In comparison with the elevated public intellectual, academics are depicted as over-specialised, technical, abstract, and aloof to social problems. ${ }^{128}$

The study of Townsley assists in providing with an example of how the already-shaped role of public intellectual can function in society against the background of competing discourses. She has also confirmed that the public intellectual as such does not exist, at the same time as demonstrating its mode of discursive existence - a person becomes a public

125 It is of relevance to take cognisance of the manner in which Townsley theorises the tropological. She distinguishes between an anthropological and sociological use, opting for the latter owing to the use of a tropological analysis that consider the "authoritative origins and political effects" of trope, since this allows also to see the way in which tropes "construct their object at exactly the same time that they hide the process of constructing it" 42. The manner in which tropes serve to create realities and what can be taken as selfevident should not be underestimated. Townsley writes: "[p]olitical tropes exercise moral power and have moral effects: readers or listeners come to expect meaning that has been normatively institutionalized in the trope over time believing that it truthfully describes reality" 42.

126 Townsley, "Public Intellectual Trope," 47.

127 Townsley, "Public Intellectual Trope," 47.

128 Townsley, "Public Intellectual Trope," 40 finds that "although there is a wide range of possible readings of the formal opposition between what is 'public' and what is 'intellectual,' in its use by contemporary political and cultural actors the "public intellectual' is always part of a criticism of the U.S. Academy." 
intellectual in a relationship of attribution and by virtue of its circulation among different discourses. To an extent this is also argued by Stefan Collini who insists on the ordinariness of intellectuals. He writes that intellectuals are ordinary "in the sense that they are indeed part of the cultural landscape of all complex societies; ordinary in the sense that it is neither unthinkable nor shocking to some of one's friends or one's colleagues or even, in some circumstances oneself." He simultaneously cautions not to catapult the public intellectual into a status of "exceptionally important," creating a kind of heroic figure in whichever manifestation. $^{129}$

According to Townsley's analysis among the public elite in the USA, "public intellecttuals" are a "good thing," and this applies not only to journalists who find in this role an aspirational possibility and an option that does not require academic legitimation, ${ }^{130}$ but also to academics even where a decline is lamented. ${ }^{131}$ Obviously public intellectuals will be a "good thing" for bureaucratic University management also because they could be a source of revenue. ${ }^{132}$ Among the academics it is especially the "cultural innovators" and the unorthodox who are associated with the trope public intellectual. ${ }^{133}$ Although Townsley's analysis pertains to a very specific group in the USA it would be possible to submit that, as a trope, it signifies social and civic ideals and regulates what is to be taken as normative and this can be asserted even where a distancing from the notion of intellectual is postured. ${ }^{134}$ The manner in which particular persons are singled out as public intellectuals and presented as social models or examples responding to their civic duties testifies to how this trope operates to normalise social behaviour. Furthermore it appears to be an ideal aspired to by both the political right and left, despite voices proclaiming anti-intellectualism at certain stages. ${ }^{135}$ The trope also functions as foil against the specialised, ivory towered mentality of academics. Albeit differently and not cast within the trope of the public intellectual self, Moraru articulates this normativity strongly when he critically presents an alternative to Gramsci: "Intellectual discourse is not superstructural to that group or base, but, against Gramsci's assumptions, structural to it, constitutive, not as much rooted in it as effectively productive of it.",136

129 Stefan Collini, “"Every Fruit-Juice Drinker, Nudist, Sandal-Wearer...': Intellectuals as Other People,” in The Public Intellectual (ed. H Small; Oxford and Malden: Blackwell Publishing, 2002), 222.

32 Townsley, "Public Intellectual Trope," 57.

133 Townsley, "Public Intellectual Trope," 57.

134 See in this regard Stefan Collini, “"Every Fruit-Juice Drinker, Nudist, Sandal-wearer...”: Intellectuals as Other People," in The Public Intellectual (ed. Helen Small; Oxford and Malden, 2002): who singles out the British, in particular George Orwell. Yet, he remarks that this critique is part of a larger pattern where those who criticise actually also should be classified as intellectuals. Neither should the disappearances or deaths claimed on behalf of the public intellectuals be seen as disclaimers, since their "absence" is on the one hand experienced as a loss and on the other hand a reaction against their representationalist capacity and the accompanying universalist claim.

135 Though anti-intellectualism, even stupidity and ignorance are sometimes claimed as default, current situation of the American society, the public intellectual still features as normative ideal to be aspired to, even on condition of being modified. On anti-intellectualism in American society see, Henry A Giroux, "Writing the Public Good Back into Education: Reclaiming the Role of the Public Intellectual," in The New Public Intellectual: Politics, Theory, and the Public Sphere (eds. Jeffrey R Di Leo and Peter Hitchcock; Hampshire and New York, N.Y.: Palgrave MacMillan, 2016):10-11; Paul A Miller, "Teaching Literature, Teaching Commitment," in the New Public Intellectual: Politics, Theory, and the Public Sphere (2016):45-46; Christian Moraru, "The Inorganic Intellectual and the Reinvention of the Communal: A Provocation," in The New Public Intellectual: Politics, Theory, and the Public Sphere (2016):63-64.

136 Moraru, "Inorganic Intellectual," 67. 
What legitimises the trope of public intellectual are the numerous discursive practices that have marked it as socio-politically and culturally ameliorative. The Dreyfus Affair has, for example, been integrated in a variety of discourses concerning radical democracy, the power of dissent, the exposure of anti-Semitism to such an extent that Collini can rather in a risky manner, tongue-in-cheek, refer to the "yearning for a more exciting state" by many British writers as, 'Dreyfus-envy'! ${ }^{137}$ And almost as if in chorus, the name of Émile Zola would appear as example of what a public intellectual signifies. Less known, yet not less valuable, is the contribution to this debate by Émile Durkheim. ${ }^{138}$ Its discursive legitimation as normative ideal should not only be seen in the historical models presented, but also in the debates, discussions, articles, in contemporary times the social media, and even in obituaries, the latter quite a testimony to the status acquired by the notion of public intellectual. ${ }^{139}$

Although offered as normative ideal, the rhetoricity of its manufacturing is seldom recognised even where cognisance has been taken of the making of its disappearance, as we have seen. To put it differently: the very discursive practices that have enabled its production and acted as its legitimation act also in the making of its decline and demise, and even as attempts at its resurrection. Where representationalism no longer functions as the primary organiser of our knowledge production and systems, where the 'essence' of the 'essential' identity upon which representation operates has proven to be a discursive construction and no longer a reflection of 'truth' or "reality' or "how things really are," the public intellectual as representative of cultural values and ideals also disintegrates. Submitting the public intellectual as "normative ideal" can obviously again be a concealed attempt at its restoration, especially with the total onslaught of identity politics and the making of types of identity politics that can be designated as identitarian. Recognising the public intellectual as a rhetorical construct or a critical rhetor, laudable as it may be, does not guarantee that the problem of representationalism has been recognised. It should be kept in mind that Quintilian's orator was to be a vir bonus and a vir bonus was to be the embodiment of Roman values and virtues, obviously those that 'reflected' the adult, elite Roman male, because an identity had to be recognised between the speech presented and the orator presenting, thereby lending credibility to a 'truth' with no discrepancy, no contradiction, no ambiguity, no discontinuity, but secure in the unity of its presentation. The identity between interior and exterior body, and between body and speech, had to secure a unity as legitimating for reliable persuasion. Although some of the sophists already problematised the identity between reality and modes of representation, the discourse that prevailed kept the identity of reality and representation safely ensconced in unity, even as the sophist tradition survived with ups-and-downs, with disruptions in what can be called a "supplementary tradition." The point is that the public intellectual can undoubtedly be cast into the mold of the critical rhetor, but that does not necessarily safeguard against a subject presenting speech that represents truth, virtue, reality, legitimated by an oratorical body that also represents these values. The problem is that the public intellectual, also as critical rhetor, has been constructed in a mode that can be identified as a metaphysical ontology ${ }^{140}$

137 Collini, "Intellectuals as Other People," 216.

138 See for example Kenneth Smith, Émile Durkheim and the Collective Consciousness of Society: A Study in Criminology (London and New York, N.Y.: Anthem Press, 2014), 188-196.

139 Townsley, "Public Intellectual Trope," 46, 49-50.

140 Bradford Vivian, Being Made Strange: Rhetoric Beyond Representation, (Albany: State University of New York Press, 2004), see especially 20-49. 
thereby continuing the very representationalism that has led to the discreditation of the category.

What needs to be recognised and elaborated is how the subjectivity of the public intellectual as rhetorical construct is the product of discursive practices. If then we maintain the public intellectual as a "normative ideal" it needs to be understood that the subject, who is the public intellectual, is formed by an already existing normative framework. To a certain extent it would be possible to define the formation of the public intellectual as a "normative ideal" in a similar manner as Butler's definition of 'sex,' albeit again running the risk of forcing the making of norms into a uniform endeavour. Borrowing from Butler's definition of 'sex' it would not be too far off the mark to find in the trope of the public intellectual "a regulatory ideal whose materialisation ... takes place through highly regulated practices." 141 Butler is here obviously referring to the hegemony of, or the hegemonic status of heteronormative sex that has been presented as the normal, the normative and the practices that have succeeded not only in its constitution but also in its maintenance and dispersion and her objective is to argue that 'sex' is not a given, is not prediscursive, that no such thing as "natural sex" exists, but that 'sex' is discursively engendered from a matrix of discursive practices that exist prior to its becoming, and acting as relations of power produce what is taken as 'sex.' Desirable as the category of the public intellectual for the maintenance of civic values, for critical public engagement, for exposing the ahistorical claims of the historical may be, its subjectivation has taken place by an interaction of discursive practices competing to produce an 'ideal' that then personifies cherished civic, cultural and political values. The public intellectual as normative ideal still presupposes a pre-existing normative framework normalising the public intellectual as desirable for society. Recognising the public intellectual as normative ideal does not sufficiently problematise representation explaining why the public intellectual is still identified with Western values, but unfortunately also misunderstanding that replacement accommodates similar problematics and, except for iuxtapositioning does not address the problem of representation's exit from functioning as primary principle for the production of knowledge.

We need to explore the possibilities Butler offers once more and introduce a quailfication that shatters the possibility of an alternative subject functioning as trope for the public intellectual while at the same time disqualifies any representation. In addition, it needs to be explained how subjectivity is engendered by discursive practices in their interaction. In a critique on constructivism that consolidates its effect into an act - a onceoff act - and replaces discourse or culture as the subject once the 'human' has been removed, she argues that materialisation is a "process that stabilizes over time to produce the effect of boundary, fixity, and surface we call matter." ${ }^{142}$ Reiteration, (repetition) is introduced as constituent element of the materialisation of subjectivity. Subjectivation takes place through process of reiteration, in which discursive practices act, not in a progressive linear, sequential mode, but in their unevenness, with interventions and disruptions, discontinuities gradually producing what we eventually would 'subjectivise.' Reiteration is a crucial constituent in the formation of subjectivity, not only because of its sedimented effect, but also because it is "by virtue of this reiteration that gaps and fissures are opened up as the constitutive instabilities in such constructions." 143 These instabilities that appear

\footnotetext{
141 Judith Butler, Bodies that Matter: On the Discursive Limits of "Sex," (New York and London: Routledge, 1993), 1.

142 Butler, Bodies That Matter, 9.

143 Butler, Bodies That Matter, 10.
} 
in reiteration are what allow for an escape from the norm, or an exceeding of that norm, that is, what also allows for difference and alterity and what also invests the subjectivated subject with agency.

It would be possible to more specifically tease out the process enacted in the becoming of the public intellectual, and setting the scene for the biblical critic as public intellectual, with the assistance of Bradford Vivian's Being Made Strange: Rhetoric beyond Representation, since his concern is indeed the constitution of the rhetor once its autonomy and representational capacity have been deconstructed. ${ }^{144}$ Vivian takes to task the manner in which the traditional rhetorical tradition has functioned as a metaphysical ontology to assist in the making of a rhetorical subject who not only signified a unity in the identity established between a bodily interiority and exterior speech, but also between speech and what were taken as universal values, thereby enacting representation as the primary principle for the production of true knowledge. Dominated by what can be described as the logic of the "what is..." question, it infuses a subject with the ability to observe the identity between an 'objective' (ideal and original) form and its subjective representations and, as such, to present being with "an essential meaning and an ideal and original form." He writes: "In metaphysical ontology, being is the transcendental signified par excellence." 145 As such "rhetoric ... was institutionalised as the civic activity through which narrow metaphysical beliefs about truth and morality, and human nature became widely accepted moral, political and cultural standards." 146 The demands to pronounce on civic duty and morality, to expose injustice and fight for justice, to function on behalf of democratic rights and represent radical democracy, to invent, maintain and disseminate knowledge that may enable coping mechanisms for the human condition, are all conditions frequently required for the making of the public intellectual (and quite remarkably also for the biblical critic), which allows for locating Vivian's rhetor within the realm of the public intellectual. It would therefore also make sense to take note of the proposal he makes for the construction of the rhetor.

Instead of an autonomous rhetor embedded within a metaphysical ontology, with rational agency and who acts to effect change or to establish a particular civility or morality, instead of a subject who is in some way or the other caught up in a representationalist logic, representing universal values embodied in 'man,' or nationalistic aspirations reflected in "the citizen," Vivian, in the wake of Michel Foucault, opts for a subject who becomes the product of discursive formations. I have indicated above that Butler (who follows, but also elaborates on Foucault) submits a subjectivity constituted by a normative ideal whose materialisation has taken place through a reiteration of discursive practices to produce the bodies they also regulate and govern. Since Vivian's concern is to loosen traditional rhetoric from its representationalistic moorings, and to depart from an autonomous subject constructed within a rhetorical situation that can be described as essentialistic, his notion of ethos which has functioned as either an element of 'character' or 'culture' can allow for how a specific subjectivity is materialised, such as the public intellectual. This can also be seen in the way he postulates the ethos of discourse as "the discursive formation of symbolic relations (social, political, and ethical) without which senses of self and other, just and unjust, or good and evil would not exist."147

\footnotetext{
144 Bradford Vivian, Being Made Strange: Rhetoric beyond Representation (Albany: State University of New York Press, 2004).

145 Vivian, Being Made Strange, 91.

146 Vivian, Being Made Strange, 92.

147 Vivian, Being Made Strange, 103.
} 
Instead of traditional rhetoric's restriction to ethos as emblem of the autonomous rhetor's character and reputation, reflecting the identity between what can be seen as 'essence' of the rhetor and the speech rendered, and constituting a particular mode of appeal, that has to serve a particular mode of appeal, Vivian resignifies ethos as the productive capacity, the mutational condition of a discursive formation. He writes: "In order to emphasise the productive capacities of form in this sense, one can profitably describe the characteristic configuration of a discursive formation as its ethos." "Since a discursive formation is engendered by difference, by its dispersion through a variety of discursive practices, it acquires a peculiar characteristic which can be seen as its ethos. To put it a bit differently: the accrual of a particular reputation happens via the repetitive dispersion of a discursive formation as it impacts and is implemented within social, political and ethical relations. However, ethos as the characteristic configuration of discursive formation should not only be seen in a general sense of the formative process by means of which discourse acquires its peculiarity through dispersion, but "[U]ltimately, its ethos is exhibited in the array of subject positions it establishes as articulations of those practices, meanings and values," that circulate as discourse. Although Vivian does not refer to the work of Pierre Bourdieu, it would be possible to closely relate his proposal of ethos with the notion of the "habituated body" when he formulates: "[T] peculiar to discursive practices, become consubstantial with or embodied in the individual ethos of specific subject positions."149

Irrespective of the origins of the public intellectual, discursive difference, transformation - even revolution - function consistently in its making. Resistance discourse gradually assumed a form when Albert Dreyfus was accused as traitor, engendering truths, normativities and ideals concerning democracy, rights, justice in its conflict with the military, the state and the church. The ethos of this discursive formation can be seen in the manner in which it has gained rhetorical value as maintaining the symbolic authority of democratic ideals, but also in the engendering of subject positions with direct effect on social and political relations. Although Émile Zola is usually exceptionalised as public intellectual in association with this trial, it can actually be demonstrated how a variety of subjectivities have been produced by this discursive formation. ${ }^{150}$ Without disregarding the role played by Zola within a logic of identity and representation, approaching the Dreyfus Affair from a rhetoric of subjectivities engendered by an ethos of discursive formation, shifts the notion of public intellectual away from exceptionality grounded in an autonomous person and expands it to enquire as to the array of subjectivities who have participated in the formation of this discourse. Such an array of subjectivities would also take into consideration those who were opposed to him, and conspired to destroy his life, not in a dichotomy of 'good' versus 'evil', but as discursive products of yet another discursive formation, namely antiSemitism, riding on the back of nationalistic discourse.

Seen from the perspective of the public intellectual as a subjectivity engendered by the ethos of discursive formation, a decisive shift has been made away from an autonomous individual representing universalities, groups or ideas. The public intellectual does not represent, but is the product of discursive formation. As a matter of fact, the public intellectual can be seen as only one of an array of subjectivities produced by an ethos of

148 Vivian, Being Made Strange, 100.

149 Vivian, Being Made Strange, 101

150 If we restrict the subjectivities engendered by this discursive formation only to notables, thereby excluding widespread public opinion and the press, it would be possible to inter alia point also to Émile Durkheim, Henri Poincaré, Georges Clemenceau, Sarah Bernhardt. 
discursive formation in turn produced by spheres of the public. To an extent it renders the constant distinction made between a public and academic intellectual superfluous, because the ethos of a discursive formation could engender a multiplicity of subjectivities as it is dispersed via social, political and ethical relations. It refuses also to be inhibited by identity politics, because the identity of the public intellectual is not constituted be particular essential features, but by an ethos of discursive practices constructing and changing subjectivities criss-crossing across boundaries and, as it is dispersed and circulated, it is also productive. This lends credibility also to the argument that the public intellectual as such does not exist, but is a rhetorical construction that is materialised through its dispersion among discourses. As an example one can again evoke the sociological findings of Townsley who, before 1987, does not encounter the notion of the public intellectual in the New York Times. Over a period of time discourse forms inter alia via reviews and interviews within which the ethos of this discursive formation engendered a subjectivity that can be seen as the public intellectual, even though lamented as having disappeared. Seen from the perspective of the ethos of its discursive formation, it also makes sense that Townsley recognised the construction of public intellectuals on the political left and right, as well as changes to its political alliances as transformations took place in American society. Since discursive formation is engendered from differences between discourses and transformations, the subjectivity emerging from its ethos does not feature within a logic of identity and unity but is subjectivated by dispersion and repeated articulations, thereby constantly acting within the realm of difference and change.

\section{Conclusion: The Public Intellectual and the Biblical Critic}

Since the origins of modern publics that can be traced to the Enlightenment, biblical scholarship's interaction with publics has always been ambivalent. Despite the fact that processes of secularisation functioned as counter strategies, biblical discourse has persistently remained part of public discourse. On the one hand it shielded itself from publics, fencing itself within the disciplinary boundaries, a move that allowed for an abundance of self-indulgent esotericism; on the other hand biblical discourse has been dispersed within a multitude of public spheres. One of the interesting paradoxes of the Enlightenment was the manner in which the Bible came to be seen as integrating and an integral part of the cultural heritage that binds together Western culture, precisely at the historical moment the authority of religion, church and monarchy was disputed. ${ }^{151}$ For our purposes the period before the dawn of the Enlightenment had already effected a paradigm shift with the inauguration of Gutenberg's printing press, as well as the Reformation, the Renaissance and the Scientific Revolution. ${ }^{152}$ Sheehan argues that two related mechanisms really drove the Reformation forward, namely translation on the one hand and biblical scholarship on the other. ${ }^{153}$ During the $16^{\text {th }}$ century an explosion of translations took place to serve the vernacular, specifically in Germany and Great Britain. The "Vernacular Bible" that thus came into existence was meant to serve the general public and translation into their own language ensured the journey to salvation. Experiencing the Reformation as a liberation from the Roman Catholic Church, biblical discourse dispersed as new translations appeared, engendering in turn further discursive formations, such as creeds and doctrines.

\footnotetext{
151 Jonathan Sheehan, The Enlightenment Bible: Translation, Scholarship, Culture, (Princeton and Oxford: Princeton University Press, 2005), xi.

152 Sheehan, Enlightenment Bible, xii.

153 Sheehan, Enlightenment Bible, xii.
} 
However, in some way or the other the authenticity and integrity of the Bible had to be retained for if this control could not be established it could result in a multitude of heresies, thereby detracting from the pure "Word of God." Biblical scholarship assumed the role of its custodian with the objective to ensure the authenticity, the integrity, the authority and the purity of biblical translations. Sheehan indicates that, in order to ensure the safe detachment from the Roman Catholic superstructure, three mechanisms were deployed, namely biblical scholarship, princely power and inspiration. ${ }^{154}$

The period of extensive translations stopped abruptly at the beginning of the $17^{\text {th }}$ century with what can be called the stabilisation of the vernacular Bible - the principle sola scriptura would not have made sense with too many scripturae circling around. Whereas scholars laboured in the $16^{\text {th }}$ century to construct a vernacular Bible through translations, consolidation stepped in during the $17^{\text {th }}$ century with biblical scholars working on the "original text," producing commentary, dictionaries and concordances and published their work in Latin. The two mechanisms that drove the Reformation, namely biblical scholarship and translation, separated as biblical scholarship busied itself with commentary, explanation and justification and translation consolidated into an acceptable vernacular Bible. Biblical translations carried the Bible into all spheres of public life, even into the realm of the family and the home, while students of the Bible could carry on with the intricacies of exegesis and understanding. It would therefore be possible to trace the outlines of an ethos of biblical scholarship, self-centred as experts and with the aspiration to regulate and maintain, to comment and explain and to distance from a wider public already to the $16^{\text {th }}$ and $17^{\text {th }}$ centuries.

However, during the $18^{\text {th }}$ century this situation was to change because the rather stable "vernacular Bible" came under attack as its insufficiencies and deficiencies gradually came to light, and the divorce that had taken place between biblical scholarship and the vernacular was suspended as biblical scholarship now had to "rescue the Bible." It was in this rescue attempt that the Enlightenment Bible was born, ${ }^{155}$ as the Bible was brought into the human world. Against criticism from philosophers and deists, but also from quasihistorical studies made on apocryphal literature during this time, the practice of a biblical scholarship that can be called a micro-ecological exercise, via specialised philology in an attempt to restore the 'real' original text from the multitude of variants that have become available via historical-critical research, came into being. Although the schism that originated between biblical scholarship and public benefit was not intentional, the 'microscopic rigour' with which biblical scholarship conducted itself did not allow for public consumption. ${ }^{156}$ An ethos developed that was infused with the desire to establish the 'original' text in a quest for historical authenticity, integrity and purity. One cannot but help recognise Foucault's diagnosis of a shift from the Classical period to Modernity, a shift that does not depart from representationalism but nevertheless installs the human being as organiser of the spectacle, as being subject but implicitly also its object, thereby integrating the constituting conditions of representationalism. The human being (Foucault's 'man') became the organising principle of knowledge production also in biblical scholarship.

54 Sheehan, Enlightenment Bible, 14.

155 Sheehan, Enlightenment Bible, 27.

156 Sheehan, Enlightenment Bible, 48-49. He writes that "Bentley and the early eighteenth-century philologians at least locked the sacred books away from public consumption, surrounding the text of the Bible with a web of specialized techniques and languages," 50. 
In inventing the biblical scholar, Moore and Sherwood ${ }^{157}$ argue that it is from the èpistémè of the Enlightenment that biblical scholarship still draws its inspiration. ${ }^{158}$ It is then also the Enlightenment Bible which has remained the Bible of contemporary biblical scholarship and which can be seen as constitutive of its ethos. In order to rescue the Bible, owing to a loss of its theological authority, the ethos of biblical scholarship was formed by discursive practices that yielded the human and cultural face of the Bible. Not only historical criticism but also literary criticism, as a matter of fact, also what they term "first wave Theory" performed to translate biblical discourse into "human and cultural categories." Taking the philosophical discourse that functioned as critique during the $18^{\text {th }}$ century they indicate to what extent the ethos of a biblical scholarship has been produced by a differentiating drive that distinguished the human and the cultural from the theological and the moral. This allowed biblical scholarship during the $18^{\text {th }}$ century to concede the pervasiveness of "biblical immoralities," such as a God who requires Abraham to sacrifice his son, or a David who conspired to have a commanding officer killed in order to seduce his wife and get away with it. ${ }^{159}$ The 'impossibility' of linking this to the divine, of allowing this type of behaviour to surface within the realm of universal morality implied its contingency to the historical and cultural environment and circumstances whence biblical discourses originated, rendering the historical the object of inquiry. Identifications with "natural religion," and a purified God, even "intrinsic morality of the true Bible" prevailed, albeit requiring rationalisations. ${ }^{160}$

To such an extent have the Enlightenment-induced discursive practices dominated the formation of biblical scholarship's ethos that the problem of biblical immorality has been eclipsed after the $18^{\text {th }}$ century. It was far more important (and easier) to settle historical problems, than to deal with a God who did not measure up to Enlightenment ideals of being human. Moore and Sherwood write: "After the eighteenth century, the investigation of biblical morality was quietly dropped from the job description of the biblical scholar. This was because the moral questions put to the Bible by the early rationalists were deemed to be irresolvable and socially corrosive, whereas historical questions were (or so it was imagined) resolvable and less incendiary." ${ }^{161}$ Although moral, ethical and theological questions would not disappear, the historical became a mechanism by means of which the former could be marginalised and rationalised. Taking Moore and Sherwood's thesis into account, it would be possible to see the contemporary biblical scholar as a subjectivity that has been engendered by an ethos of biblical scholarship of which discursive practices requiring a focus on the historical reigned supreme. The foreignness of the 'other,' its immoralities and its subhuman tendencies could be kept at a distance, while the immediacy of Enlightenment culture could be retained by the identification of a minimal core, or a

157 Although the publication, The Invention of the Biblical Scholar: A Critical Manifesto (Minneapolis: Fortress Press, 2010) has been jointly published by Stephen D Moore and Yvonne Sherwood, it appears from Stephen D Moore and Yvonne Sherwood, "Biblical Studies 'After' Theory: Onwards Towards the Past, Part Two: The Secret Vices of the Biblical God" Biblical Interpretation 18 (2010):87 that Sherwood was the primary author of what has here been reproduced. Since both publications have been published under both names I will retain both names in referencing.

158 Stephen D Moore and Yvonne Sherwood, "Biblical Studies 'After' Theory: Onwards Towards the Past, Part Two: The Secret Vices of the Biblical God,” Biblical Interpretation 18 (2010):88-80. Stephen D Moore and Yvonne Sherwood, The Invention of the Biblical Scholar: A Critical Manifesto, (Minneapolis: Fortress Press, 2011), 46-48.

159 Moore and Sherwood, "Secret Vices," 94-99; Moore and Sherwood, "Invention of Biblical Scholar,"54-58.

160 Moore and Sherwood, "Secret Vices," 97-100; Moore and Sherwood, "Invention of Biblical Scholar," 49-58.

161 Moore and Sherwood, "Secret Vices,"101; Moore and Sherwood, "Invention of Biblical Scholar," 59. 
more pure original, an intrinsic morality that found its substantiation in a transcendentalist metaphysics, and last but not the least an autonomous biblical scholar posturing as the expert, the historian fitted within this transcendalist narrative in its quest for origins. During this formative period of biblical scholarship it became possible to enquire historical problems ad infinitum, also in interdisciplinary sense, the requirement being the accuracy of the representation and the incorporation of terminologies and strategies that could enhance the precise correspondence. The ethos of biblical scholarship engendered by discursive practice created subjectivities that could be called what Blanton has named as "measurers of the past." 162

Although it would be possible to point to advances that have been made away from the hegemony of historical and more recently literary biblical scholarship owing to increasing input from feminism and post-colonialism, poststructuralism and the variety of theoretical paradigms that have been appropriated by Biblical Studies, the question is to what extent the Enlightenment Bible is not still setting the agenda, quite often in a very concealed manner.

Taking biblical scholarship to task for neglecting to recognise the cultural performativity of biblical discourse by functioning as curators or advertisers for biblical cultural artefacts, Clines self-critically reflects that "we have convinced ourselves that our business is simply to understand, to interpret. Here we have some difficult texts from the ancient world, we say, rightly enough. Do you want to know what they mean? Then come to us, we are the experts, we understand them, we shall tell you how to interpret them."163 Comparing literary critics and biblical scholars, Moore concurs, writing: "Biblical scholars ... tend to refer to themselves as 'biblical critics' just as infrequently as literary critics refer to themselves as 'literary scholars.' Biblical scholars continue to labour under the imperative to mark themselves as scholars." 164 It is in the innocent sounding, apparently neutral designation 'scholar' that we need to see something of how power performs as discourse. That the designation 'scholar' claims discursive legitimacy for the critic, and the process of a body materialised by discursive practice, and circulated within an environment where a variety of technologies cooperate in its maintenance, cannot be denied. It is precisely when these technologies and practices are recognised that we are able to see how autonomy and representation are at work in the performativity of the term 'scholar.' Politicised institutional regulatory mechanisms actively intervene in controlling the production of knowledge, just as disciplinary practice constrains privileging and stimulating particular fields while implementing exclusionary techniques for others. To be a "biblical scholar" presupposes expert knowledge concerning biblical material, a trained mind that has been subjected to years of study, sacrifice, but also institutional surveillance backed by national and international accreditation. To be a scholar indeed implies to belong to that privileged social field where the vulgar phrase "credence goods" indeed applies. Not only does this individual really know how things biblical "really were," what the 'fundamental' or 'essential' facts of antiquity were, but as representative of a particular interpretative community, there is also an accountability at stake that requires social respect. The rhetoric of a presumably innocent designation such as "biblical scholar" at the cost of "biblical critic," not only maintains a particular social hierarchy, the status of an exclusionary expert,

\footnotetext{
162 Ward Blanton, Displacing Christian Origins: Philosophy, Secularity, and the New Testament, (Chicago and London: The University of Chicago Press, 2007), 12.

163 David JA Clines, Bible in Modern World, (Sheffield: Phoenix Press, 2005), 23.

164 Stephen D Moore and Yvonne Sherwood, The Invention of the Biblical Scholar: A Critical Manifesto, (Minneapolis: Fortress Press, 2011), 77.
} 
simultaneously upholding the 'truth' of certain statements concerning the object of inquiry, while resisting others, but it also keeps the critic into the position of commentator, explaining, interpreting for, solving biblical problems of a historical nature and providing solutions.

It stands to reason that the notion of 'scholar' also performs citing the condition of objectivity. For that reason, Clines sarcastically exclaims in response to a demand for evaluation or critique as characteristic of the biblical critic's job description: "Oh no, we are objective scholars, and we prefer to keep hidden our personal preferences and our ethical and religious views about the subject matter of our study." ${ }^{165}$ This echoes Schüssler Fiorenza's problematisation of biblical studies pointing right to its ethos as the heart of the problem, an ethos, constituted by what is seen as scientific value-free inquiry. ${ }^{166}$ The configuration that has cooperated in constructing the ethos of the "biblical scholar" consists of the detached, socially disinterested expert, autonomous, serving a particular community with explanation, laying bare "what the text means," according to and with the sanitising methodological vocabularies available which are likewise justified as 'objectively' appropriate for inquiring the object.

In a similar manner can the often used 'voices,' as referring to particular identities, allow for a replication of an enlightenment logic of representation. It has become almost standard to refer to "marginalised voices," or "voices from the margins," or if then not necessarily from the margin, voices from somewhere, that is from a specific place or demarcated space, as long as this is not Western, European or North American. Needless to point out that identity politics is the driving force in these attempts to thwart exclusion and struggle for inclusion, and the inroads that have been made, the colonialist walls that have been scaled and the old boys clubs that have been penetrated cannot but be lauded and appreciated. However, the metaphoric 'voice' firmly entrenches a logic of representationalism, just as the use of spatial rhetoric imposes a confusing homogeneity, veiling a discursive heterogeneity and not subverting essentialistic identity constructions. Rhetorically the metaphor 'voice' evokes a corporeality, a particular body who must be heard; there is an immediacy of communication not conveyed by the act of writing, a face-to-face encounter, an interpellation that eclipses the insistence from a page of writing. The concern is speech and the condition that allows it legitimacy is the assumption of an identity with truth - this voice speaks the truth, and this voice speaks the truth of others and on behalf of others. Besides the fact that these 'voices' may be nothing but a ventriloquesting of the master's voice, the rhetoric of representation should not be underestimated.

Thinking the biblical critic as public intellectual evokes its rhetorical constitution. We have seen that the public intellectual can be seen as a rhetorical construct, a subjectivity whose ethos has discursively been formed by a variety of discursive practices. As such, the biblical critic cannot be seen as an autonomous voice, a subject in the active voice functioning as authoritative representative of a fixed, demarcated corpus of knowledge, assumed to have been accumulated and granted status of truth on the basis of consensus. Recognising the biblical critic as public intellectual seeks to construct an identity whose accountability is not restricted to disciplinary boundaries but whose formation is subject to constantly changing and shifting discursive practices and who is also repeatedly dispersed among these discourses, whose discursive mode of existence is subjected to a logic of

165 Clines, Bible in Modern World, 23.

166 Elisabeth Schüssler Fiorenza, "The Ethics of Biblical Interpretation: Decentering Biblical Scholarship," in Rhetoric and Ethic: The Politics of Biblical Studies (ed. Elisabeth Schüssler Fiorenza; Minneapolis: Fortress Press, 1999), 22. 
difference and not to a logic of identity within which difference only functions as measure of identity.

The question is whether it would not more effectively serve the transformation of Biblical Studies and expedite a recognition of its publicness if a revised version of the public intellectual's discursive formations can perform as constitutive in the formation of the biblical critic's ethos? What could happen if the discursive practices performing the making of the ethos of the biblical critic are identified and inquired? If the public intellectual as a subjectivity engendered by the ethos of discursive practices can function as constitutive to the ethos of the biblical critic, what would be the possibilities for a recognition of how discursive differences instead of representation can organise our production of knowledge in emerging democracies? What could be the effects if the biblical critic is recognised as a subjectivated capacity, a subjectivity performing difference, not as a conduit of information but as a discursive catalyst for change?

\section{BIBLIOGRAPHY}

Bitzer, Lloyd 1968. "The Rhetorical Situation.” Philosophy and Rhetoric 1(1):1-14. Blanton, Ward 2007. Displacing Christian Origins: Philosophy, Secularity, and the New Testament. Chicago and London: The University of Chicago Press.

Butler, Judith 1993. Bodies That Matter: On the Discursive Limits of "Sex." New York and Routledge: Routledge.

Brantlinger, Patrick 2003. "Professors and Public Intellectuals in the Information Age." Shofar: An Interdisciplinary Journal of Jewish Studies 21(3):122-136.

Calavita, Kitty 2002. “'Goose Bumps,' and the Role of the Public Intellectual," Law \& Society Review 36(1):5-20.

Carroll, David 2008. "The End(s) of the Intellectual: Ethics, Politics, Terror." South Central Review 25(3):106-125.

Clines, David JA 2005. The Bible in the Modern World. Sheffield: Phoenix Press.

Collini, Stefan 2002. “'Every Fruit-Juice Drinker, Nudist, Sandal-Wearer...': Intellectuals as Other People.” Pages 203-223 in The Public Intellectual. Edited by H Small. Oxford and Malden: Blackwell Publishing.

Crick, Nathan 2006. "Rhetoric, Philosophy, and the Public Intellectual." Philosophy and Rhetoric 39(2):127-139.

Dean, William D 1994. The Religious Critic in American Culture. Albany: State University of New York Press.

De La Campa, Roman 2003. “On New American Subjects and Intellectual Models." Nepantla: Views from South 4(2):253-243.

Di Leo, Jeffrey R 2006. "Public Intellectuals, Inc.” Symplokê 14(1-2):183-196.

Di Leo, Jeffrey R 2016. The New Public Intellectual: Politics, Theory, and the Public Sphere. Hampshire and New York, N.Y.: Palgrave MacMillan.

Dreyfus, Hubert L and Rabinow, Paul 1983. Michel Foucault: Beyond Structuralism and Hermeneutics. $2^{\text {nd }}$ ed.; Chicago: The University of Chicago Press.

Foucault, Michel 1994. The Order of Things: An Archaeology of the Human Sciences.

New York: Vintage Books. 
Foucault, Michel 1998. "What is An Author?" Pages 205-222 in Michel Foucault: Aesthetics. Vol. 2 of Essential Works of Foucault 1954-1984. Edited by James D Faubion. Translated by R Hurley. Harmondsworth: The Penguin Press.

Foucault, Michel 1998. "On the Archaeology of the Sciences: Response to the Epistemology Circle.” Pages 297-333, in Michel Foucault: Aesthetics. Vol. 2 of Essential Works of Foucault 1954-1984. Edited by James D Faubion. Translated by R Hurley. Harmondsworth: The Penguin Press.

Foucault, Michel 2001. "Truth and Power." Pages 111-133 in Michel Foucault: Power. Vol. 3 of Essential Works of Foucault 1954-1984. Edited by James D Faubion. Translated by R Hurley and others. Allen Lane: The Penguin Press.

Foucault, Michel 2003. "The Masked Philosopher.” Pages 174-179 in Michel Foucault: Ethics. Vol. 1 of Essential Works of Foucault 1954-1984. Edited by P Rabinow and N Rose. Translated by A Sheridan. New York and London: The New Press.

Fuller, Steve. The Intellectual. Cambridge: Icon Books, 2005.

Fuller, Steve 2006. "The Public Intellectual as Agent of Justice: In Search of a Regime." Philosophy and Rhetoric 39(2):147-156.

Fuller, Steve 2013. "Entertainment as Key to Public Intellectual Agency: Response to Welsh." Philosophy and Rhetoric 46(1):105-113.

Giroux, Henry A 2016. "Writing the Public Good Back Into Education: Reclaiming the Role of the Public Intellectual.” Pages 3-28 in The New Public Intellectual: Politics, Theory and the Public Sphere. Edited by J Di Le and P Hitchcock. Hampshire and New York: Palgrave Macmillan.

Glaude, Eddie S 2003. “On Mendieta's Latino Public Intellectual.” Nepantla: Views from South 4(2):257-261.

Jacoby, Russell 1987 [2000]. The Last Intellectuals: American Culture in the Age of Academe. New York: Basic Books.

Jansen, Johnathan 2009. "South Africa: Intellectuals, the State and the Universities," Poverty of Ideas - South African Democracy and the Retreat of Intellectuals. Edited by Gumede, William M and Dikeni, Leslie. Johannesburg: Jacana Media. Obtained from University World News at http://www.politicsresearch.com/article.php (December 13, 2009).

Jennings, Jeremy 2002. "Deaths of the Intellectual: A Comparative Autopsy." Pages 110-130 in The Public Intellectual. Edited by Helen Small. Oxford and Malden: Blackwell Publishing.

Johnson-DeBaufre, Melanie 2010. "Mapping the Field, Shaping the Discipline: Doctoral Education as Rhetorical Formation." Pages 319-353 in Transforming Graduate Biblical Education: Ethos and Discipline. Edited by Elisabeth. Schüssler Fiorenza and Kent H Richards. SBL Global Perspectives on Biblical Scholarship 10. Atlanta: Society of Biblical Literature.

Juffer, Jane 2003. "In Search of the Latino Public Sphere: Everywhere and Nowhere." Nepantla: Views from South 4(2):263-268.

Lyotard, Jean-François 1993. "Dead Letter (1962)." Pages 33-40 in Political Writings: Jean-François Lyotard. Edited by B Readings. Translated by B Reading with KP Geiman. London: University College London 
Lyotard, Jean-François 1993. "New Technologies (1982)." Pages 14-18 in Political Writings: Jean-François Lyotard.

Lyotard, Jean-François 1993. “The Differend (1982).” Pages 8-10 in Political Writings: Jean-François Lyotard. Edited by B Readings. Translated by B Reading with KP Geiman. London: University College London

Lyotard, Jean-François 1993. “Tomb of the Intellectual (1983).” Pages 3-7 in Political Writings: Jean-François Lyotard.

Lyotard, Jean-François 1993. “The Grip (1990).” Pages 148-158 in Political Writings: Jean-François Lyotard.

Mailloux, Steven 2003. “Contingent Universals: Religious Fundamentalism, Academic Postmodernism, and Public Intellectuals in the Aftermath of September 11." Cordoza Law Review 24(4):1583-1604.

Mailloux, Steven 2006. "Thinking in Public with Rhetoric." Philosophy and Rhetoric 39(2):140-146.

Martinez, Jacqueline M 2003. "On the Possibility of the Latino Postcolonial Intellectual." Nepantla: Views from South 4(2):253-256.

McCutcheon, Russell T 1997. "A Default of Critical Intelligence? The Scholar of Religion as Public Intellectual." Journal of the American Academy of Religion 65(2):443-468.

Mendieta, Eduardo 2003. "What can Latinas/os Learn from Cornel West? The Latino Postcolonial Intellectual in the Age of the Exhaustion of Public Spheres. Nepantla: Views from South 4(2):213-233.

Miller, Paul A 2016. "Teaching Literature, Teaching Commitment.” Pages 44-59 in The New Public Intellectual: Politics, Theory and the Public Sphere. Edited by J Di Leo and P Hitchcock. Hampshire and New York: Palgrave Macmillan.

Moore, Stephen D and Sherwood, Yvonne 2010. "Biblical Studies 'After' Theory: Onwards Towards the Past, Part Two: The Secret Vices of the Biblical God." Biblical Interpretation 18:1-27.

Moore, Stephen D 2010. "Illuminating the Gospels Without the Benefit of Color: A Plea for Concrete Criticism." Pages 27-52 in After "After Theory, " and Other Apocalyptic Conceits in Literary and Biblical Studies. Edited by SD Moore. SBL Resources for Biblical Study 57. Atlanta: Society of Biblical Literature.

Moore, Stephen D and Sherwood, Yvonne 2010. The Invention of the Biblical Scholar: A Critical Manifesto. Minneapolis: Fortress Press.

Moraru, Christian 2016. "The Inorganic Intellectual and the Reinvention of the Communal: A Provocation." Pages 63-77 in The New Public Intellectual: Politics, Theory, and the Public Sphere. Edited by J Di Leo and P Hitchcock.

Moya, Paula M L 2003. "With Us, or Without Us: The Development of a Latino Public Sphere.” Nepantla: Views from South 4(2):245-252.

Nethersole, Reingard 2011. "JM Coetzee: Reluctant Public Intellectual." African Yearbook of Rhetoric 2(1):41-51.

O'Connor, June 1998. "Response: The Scholar of Religion as Public Intellectual: Expanding Critical Intelligence." Journal of the American Academy of Religion 65(4):897-909.

Oksala, Johanna 2007. How to Read Foucault. London: Granta Books. 
Posner, Richard A 2001. Public Intellectuals: A Study of Decline. Cambridge and London: Harvard University Press.

Readings, Bill 1993. "Foreword: The End of the Political." Pages xiii-xxvi in Political Writings: Jean-François Lyotard. Edited by B Readings. Translated by B Readings and KP Geiman. London: University College London.

Ryan, Vanessa L 2007. “'Considering the Alternatives...:' Shaw and the Death of the Intellectual.” SHAW The Annual of Bernard Shaw Studies 27:175-189.

Sheehan, Jonathan 2005. The Enlightenment Bible: Translation, Scholarship, Culture. Princeton and Oxford: Princeton University Press.

Schüssler Fiorenza, Elisabeth 1999. "The Ethics of Biblical Interpretation: Decentering Biblical Scholarship." Pages 17-30 in Rhetoric and Ethic: The Politics of Biblical Studies. Edited by E Schüssler Fiorenza. Minneapolis: Fortress Press.

Schüssler Fiorenza, Elisabeth 1999. "Introduction: For a Biblical (Wo/man) Scholar to Speak in the Ekklesia..." Pages 1-14 in Rhetoric and Ethic: The Politics of Biblical Studies.

Schüssler Fiorenza, Elisabeth 1999. "The Ethics of Biblical Interpretation: Decentering Biblical Scholarship." Pages 17-30 in Rhetoric and Ethic: The Politics of Biblical Studies.

Schüssler Fiorenza, Elisabeth 1999. "Changing the Paradigms: The Ethos of Biblical Studies.” Pages 31-55 in Rhetoric and Ethic: The Politics of Biblical Studies.

Schüssler Fiorenza, Elisabeth 2010. "Rethinking the Educational Practices of Biblical Doctoral Studies." Pages 373-393 in Transforming Graduate Biblical Education: Ethos and Discipline. SBL Global Perspectives on Biblical Scholarship 10. Edited by E Schüssler Fiorenza and KH Richards. Atlanta: Society of Biblical Literature.

Sim, Stuart 1996. Jean-François Lyotard. London: Prentice Hall Harvester Wheatsheaf.

Smith, Kenneth 2014. Emile Durkheim and the Collective Consciousness of Society: A Study in Criminology. London and New York: Anthem Press.

Townsley, Eleanor 2006. "The Public Intellectual Trope in the United States." The American Sociologist 37(3):39-66.

Vatz, Richard E 1973. "The Myth of the Rhetorical Situation.” Philosophy and Rhetoric 6, no. 3 (1973):154-171.

Vivian, Bradford 2004. Being Made Strange: Rhetoric Beyond Representation. Albany: State University of New York.

Vorster, Johannes N 1994. "The Context of the Letter to the Romans: A Critique on the Present State of Research.” Neotestamentica 28(1):127-145. 